\title{
Attitudes and Self- Efficacy of Students toward Mathematics
}

\author{
Jay Ar I. Laranang ${ }^{1}$, John Mark F. Bondoc ${ }^{2}$
}

${ }^{1}$ Mariano D. Marquez Memorial National High School, Simbahan, Dinalungan Aurora, Philippines

${ }^{2}$ Wesleyan University-Philippines, College of Education, Mabini Extension, Cabanatuan City, Nueva Ecija, Philippines

\begin{abstract}
The study aimed to assess the attitudes and self-efficacy of junior high school students towards mathematics performance for the school year 2019-2020 using a descriptive-correlational survey research design. An adapted questionnaire was answered by 267 junior high school students. The data was statistically analyzed using mean, Pearson product-moment correlation, and Spearman Rho for the significance of p-value as statistical tools. The respondents' first-quarter grade was described as approaching proficiency, which means students performed not very well in their mathematics performance.
\end{abstract}

Attitudes of the respondents towards mathematics were evaluated in areas of self-confidence, value, enjoyment, and motivation. Junior high school students had a moderately high level of self-confidence in mathematics and enjoyed studying mathematics. They had a high level of attitude in valuing mathematics as they believed mathematics is essential in everyday life, and it helps them develop the mind and teaches them to think. They also had a high level of attitude in terms of their enjoyment in learning mathematics subjects because they believe studying mathematics helps them with problem-solving in other areas it is useful. They also think that having a strong background in mathematics could help them in their professional life. The students had a moderately high level of attitudes in terms of motivation in learning mathematics as they feel nervous and makes them feel uncomfortable during mathematics class. Students' self-efficacy in mathematics was moderately high because of the belief they will be able to use mathematics in future careers when needed. A significant relationship between students' profile and their level of attitudes in self-confidence, value, enjoyment, and motivation in learning mathematics was investigated. It was found out that respondents' sex, most liked and disliked subject has a significant relationship with their self-confidence. Their value of mathematics was significantly related to their parents' education, mothers' occupation, parents' monthly income, gadgets used in learning mathematics, and most liked the subject. Enjoyment in learning mathematics was significantly related to students' daily allowance, devices used in learning mathematics, and most enjoyed subjects. Their motivation was significantly associated with their most liked subject. Profile variables of the students were correlated to their level of self-efficacy and mathematics performance. Among the profile variables, the most wanted subject was with a significant relationship with their self-efficacy. Simultaneously, mathematics performance was significantly related to their sex, parents' education, mothers' occupation, and gadgets used in learning mathematics. Attitudes of junior high school students towards mathematics were significantly correlated to their self-efficacy in mathematics.

This study recommends that students may make some effort to improve their performance in mathematics. Their attitudes towards mathematics should be improved to enhance their self-confidence, motivation, and self-efficacy in mathematics.

Keywords-Attitudes, self-efficacy, motivation, self-confidence, enjoyment, value, performance.

ISSN: 2456-7620 


\section{INTRODUCTION}

Mathematics is one subject that pervades life at any age and in any circumstance. Thus, its value goes beyond the classroom and the school. Mathematics, as a school subject, therefore, must be learned comprehensively and with much depth (Department of Education, 2013). Mathematics is a relevant subject in the modern education of the youth. It is a vital significance as it permeates the daily lives of people around the world. It serves as the basis of modern inventions, scientific discoveries, and research studies (Pilayan, 2013).

It is also a tool that can be used to solve the problems in daily life. Due to this, mathematics has been considered one of the most critical allied subjects in a secondary school curriculum. It is an essential subject in the high school curriculum that links algebra, geometry, and trigonometry (Pilayan, 2013).

Furthermore, the study of mathematics at the secondary level is necessary for the foundation stage of higher education. Every secondary school student should study mathematics as a compulsory subject.

However, negative attitudes toward mathematics are common (McNaught, 2010; Blackweir, 2016). Whether anecdotally identified as "Mathemaphobia" (Chukus 2012; Blackweir, 2016) or from a phenomenological perspective as disaffection (Blackweir, 2016), mathematics has been burdened with a severe image problem. Furthermore, because attitudes towards mathematics depend on the experiences of individual students, significant differences can be found between one class and another as well as between students in the same mathematics class (Noyes, 2012).

Moreover, the attitude of students towards mathematics is one of the factors for learning mathematics. The study conducted by Mogensen (2011) revealed that experiences result in changes in the brain and suggest that motivation should be affected and treated seriously when a school culture makes students keep low profiles to avoid being labeled. Self-confidence and good role models amongst classmates and teachers are decisive for students' attitudes towards the subject. Thus, the philosophy of students towards mathematics is one of the factors for learning mathematics. Furthermore, the study of Elci (2017) revealed that students' attitudes towards Mathematics have significance in attaining success.

Similarly, self-efficacy in Mathematics is also a decisive factor. Several studies revealed the strong relationship between self-efficacy and Mathematics performance (Pampaka et al., 2011; Fast et al., 2010; Liang, 2010; Tudy, 2014). Maximizing the impact of self-efficacy, Cheema (2013), as cited by Tudy (2014), concluded that basic and simple measurements of math self-efficacy are likened to the effectiveness, such as the mathematically elegant and complex counterparts. Self-efficacy in Mathematics is strongly related to the students' attitudes towards the subject. The former also showed a significant effect on the tertiary entrance ranks (Vukovic et al., 2013; Tudy, 2014).

According to Bandura (1997), self-efficacy is related to personal perception of a person's capacity to plan and execute actions to achieve specific goals. Self-efficacy is measured according to the level of the person's certainty for carrying out a particular task. It is task-specific, related to the perception about the difficulty level that a person has for a specific job (Zimmerman, 2000, Bondoc, 2015) and also context-specific referring to the context of the task (Bong \& Skaalvik, 2003; Linnerbrick \& Pintrich, 2003; Bondoc, 2015). As Bandura argues (1981), self-efficacy is the best means of measuring an action's level of success as it focuses on the specific action each time.

Since attitudes and self-efficacy in mathematics affect the performance in mathematics, low performance in Mathematics is also a problem in the Philippines. For instance, in the result of the Third International Mathematics and Science Study ranked the Philippines (TIMSS) as 39th out of 41 participating international countries (Mullis et al. Hinor, 2007) as cited by Villaver (2014). This showed that Filipino students could not go beyond simple recall. They could not fully comprehend the questions, thus leading to a wrong answer. Mathematics performance, as measured by the National Achievement Test (NAT) result is below the $50 \%$ required by DepEd. In 2009, even with only the science high schools participating in the Advanced Mathematics category, the Philippines ranked lowest (Department of Education, 2010).

Moreover, the Division of Aurora experiences problems in Mathematics performance, as seen in the NAT result released by the National Education Testing and Research Centre (2012). The division's Mean Percentage Score (MPS) is 52.0, ranked 58 out of 191 divisions in the country.

Besides, the researcher worked in Mariano D. Marquez Memorial National High School for three years as a 
secondary school teacher and assessed the mathematics performance and potential of students and found out. Students experienced difficulty in Mathematics. Most of them do not perform the task given by the teacher. In quizzes, students got very low scores. When performing their seat works, some of the students have only a few are passed the examination, and most of them would take the remedial investigation to pass the subject.

Moreover, the researcher observed that attitude and self-efficacy are the factors of teaching mathematics to secondary students. Several studies revealed that positive attitudes are conducive to good achievement in mathematics. Furthermore, regarding school mathematics, self-efficacy is found to be one of the most critical variables for explaining the difference in mathematics performance of students that explains a quarter of the variance while predicting students' mathematics achievement ( Recbar et al., 2018).

Dika and Langat, 2015 revealed a complexity of interrelated factors that have been found to influence learners' attitudes and self-efficacy achievements in mathematics. Several researchers have regarded attitudes and self-efficacy as a critical factor to be considered when attempting to understand and explain variability in student achievement.

It is, therefore, essential to understand the students' attitude and self-efficacy and its relationship to their mathematics performance. The researcher believed that knowing the students' attitude, self-efficacy, mathematics performance, and the relationships among these variables will help the teachers to have a strong basis in building their students' attitudes and self-efficacy alleviating their mathematics math performance.

\section{Attitude towards Mathematics}

Attitude, a hard to define the concept, is "a learned disposition or tendency on the part of an individual to respond positively or negatively to some object, situation, concept or another person" Recber, (2018). In mathematics, Recber (2018) indicated the inconsistent research findings regarding the relationship between attitude towards mathematics and mathematics achievement. While some researchers reported a statistically significant relationship (Michelli, 2013; Recber, 2018), others stated a statistically significant but not strong relationship between attitude towards mathematics and mathematics achievement investigated the causal ordering between mathematics attitude and mathematics achievement of secondary school students. Students were randomly selected from seventh graders and were followed for six years until they reached 12th grade. Students completed achievement tests on necessary skills, algebra, geometry, and quantitative reasoning and a questionnaire regarding attitude towards mathematics. Data analysis revealed that for all grade levels, prior achievement significantly predicts future attitude. However, prior attitude does not significantly predict future achievement. Thus, researchers emphasized the predominance of achievement over attitude in secondary school years.

Similarly, in a recent study, Soleymani and Rekabdar (2016) investigated the relationship between undergraduate students' mathematics achievement and attitudes toward mathematics. They reported that previous performance has a positive effect on attitude towards mathematics. However, the effect of attitude on final grade was not statistically significant. Specific theories give an insight into how attitudes may be changed; "Learning Theory of Attitude Change: Classical conditioning, operant conditioning, and observational learning can be used to bring about attitude change. Classical conditioning can create positive emotional reactions to an object, person, or event by associating positive feelings with the target object. Operant conditioning can be used to strengthen desirable attitudes and weaken undesirable ones. People can also change their attitudes after observing the behavior of others. Elaboration Likelihood Theory of Attitude Change: This theory of persuasion suggests that people can alter their attitudes in two ways. First, they can be motivated to listen and think about the message, leading to an attitude shift. Or, they might be influenced by the characteristics of the speaker, leading to a temporary or surface shift in attitude. Messages that are thought-provoking and that appeal to logic are more likely to lead to permanent changes in attitudes. Dissonance Theory of Attitude Change: people can also change their attitudes when they have conflicting beliefs about a topic, subject, or issue. To reduce the tension created by these incompatible beliefs, people often shift their attitudes"(Kendura, 2013; Langat 2015).

\section{Attitudes of Students and their Performance in Mathematics}

Attitudes are defined approaches an organization of several beliefs focused on a specific object or situation tendency to respond in some preferential manner (Rokeach, 1972 as cited in Martino and Zan, 2001; Elci, 2017). Thurston (1929) also defined the attitude as a combination of 
tendencies, human emotions, fears, beliefs about a particular problem, and prejudices Elci (2017). Neale (1969) defined the attitude towards mathematics as a person's tendency to like or to hate mathematics, to deal with or to avoid from mathematical activities, his or her belief of being successful or not in mathematics, or a belief that mathematics was useful or not (Elci, 2017).

Researchers (Attard, 2012; Mata, Monteiro, \& Peixoto, 2012) have identified important factors contributing to students' attitudes towards learning mathematics. These include the students themselves, the school, the teachers' beliefs, and attitudes, and their teaching methods.

The teachers' teaching method significantly influences students' attitudes (Mensah et al., 2013). Teachers can do many things to facilitate classroom learning to alleviate students' engagement level and confidence in learning mathematics (Attard, 2012; Kele \& Sharma, 2014). This can be achieved by implementing meaningful activities embedded in real-life contexts (Kacerja, 2012).

Most research on attitudes points to the fact that attitude plays a crucial role in learning and achievement in mathematics (Zan and Martino, 2007; Langat, 2015) hence determines the student's success in the subject. It determines their ability and willingness to learn the subject, work on various assigned tasks, and their persistence in the functions available. In general, the conceptions students hold about Mathematics determine how they approach mathematics tasks leading them into productive or nonproductive orientations. In many cases, students have been found to approach Mathematics as procedural and rule-oriented. This prevents them from experiencing the richness of Mathematics and the many approaches used to develop competence in the subject (Mensah et al., 2013).

\section{Mathematics Self-Efficacy}

Albert Bandura defined self-efficacy as "beliefs in one's capabilities to organize and execute the courses of action required to produce given attainments" (Bandura, 1997 as cited by Causapin, 2012). People who have firm self-efficacy beliefs in a domain "act, think, and feel differently" from low self-efficacy (Bandura, 1984). They are more persistent, more effective, and more self-regulated (Pajares \& Urdan, 2009). Bandura hypothesized that this belief is domain-specific, which means it cannot be expected that a person is self-efficacious in all human endeavors (Bandura, 1997).
Mathematics self-efficacy is the belief in one's ability to learn and succeed in school mathematics. A student's conviction that adopting certain behaviors will result in achievement in the mathematics classroom; however, the student defines it. This belief was shown to predict mathematics performance better than any other mathematics-related belief constructs (Liu, 2009). Other factors, apart from self-efficacy can guide and motivate students. When students do not believe in their ability to succeed in each task, they need to have much higher selfcontrol and motivation to achieve. Unfortunately, students who have low self-efficacy are less likely to regulate their achievement behaviors or be motivated to engage in learning (Klassen and Usher, 2010; Schunk and Pajares, 2009).

Self-efficacy is not merely a reflection of past achievements (Bandura, 1997). There are capable students with low and high self-efficacies, and there are less capable ones with varying levels of this belief ( ICaupasin, 2012). Furthermore, high self-efficacy causes changes in behaviors that influence future performance regardless of previous achievement (Caupasin, 2012).

\section{Theoretical Framework}

The study is anchored on the cognitive theory of psychopathology of Beck (2011). He developed a comprehensive theoretical model called the cognitive model. This model describes how people's thoughts and perceptions influence their lives. It explains individuals' emotional, physiological, and behavioral responses as mediated by their perceptions of experience, which are influenced by their beliefs and distinct ways of interacting with the world and their experience. In this study, the cognitive model comprises the students' attitude towards mathematics; and self-efficacy in mathematics and its influence in mathematics performance. Students' attitude towards mathematics and mathematics self-efficacy describes how students' thoughts and perceptions influence their mathematics learning.

Nicolidau and Philippou (2008; Repuya, 2018) stressed that thoughts or the attitude of the students towards mathematics start in the early years of schooling. They emphasized that the teachers in high school have the opportunity and responsibility to promote and even enhance a positive attitude towards mathematics. They further explained that fostering a positive attitude towards mathematics to students can influence their mathematics performance. 
This study is related to the studies mentioned earlier. However, it differs in some aspects. The studies of Nicolidau and Philippou (2008), Klomegah (2007), and Smith et al. (2006) all agreed that math performance is affected by the behavior of the learner towards mathematics. Hoffman and Schraw (2006), Fast et al. (2010), and Liu and Koiala (2009) are all in consensus as well that math selfefficacy is a strong predictor of mathematics performance. Phillips (2015) and Cadorna et al. (2016) both agreed that teachers could do a lot in helping the students overcome their fear of the subject. The methodology of this study is different from the previous studies in that it determined the influence of thoughts (ATM) and beliefs (MSE) on students' mathematics performance.

\section{CONCEPTUAL FRAMEWORK}

In this study, the cognitive model comprises the students' attitude towards mathematics; and self-efficacy in mathematics and its influence in mathematics performance.

Students' attitudes and self-efficacy describes how student's thought and perceptions influence their mathematics learning. Student's thoughts reflected in their attitudes toward mathematics will lead to a specific outcome because of their actions. Having a positive attitude means that whatever happens, there is something good that can be expected from it if efforts were exerted. Negative emotional dispositions towards mathematics might be associated with different patterns of attitude, depending on the students' perceived competence and vision of mathematics and the relationship amongst the three dimensions. The Attitude toward mathematics of the student along emotional disposition must not only be considered as unfavorable; hence when at least one of the dimensions is negative, students' negative attitude towards mathematics can be profiled depending on the dimension that appears negative. It means that the students' negative attitude starts with any of the three dimensions. Mathematics self-efficacy affects the attitude and the behavior one holds towards mathematics and the motivation and the confidence to perform well.

Self-efficacy is the most influential predictor of human functioning. In this study, the student's belief in their performance affects their behavior on how they will function in performing mathematics tasks. Students with a high sense of self-efficacy exhibit strong motivation and approach difficulties as challenges to be mastered, whereas students with a low sense of self-efficacy exhibit weak commitment and approach difficulties as threats and anxiety.

Using this framework and the above discussion, the researcher believes that the profile of respondents and the attitudes and the levels of their self-efficacy in mathematics is related to their mathematics performance.

The research paradigm shows the interrelationship of students' profiles, attitudes, self-efficacy, and their effect on their performance in mathematics. Moreover, the researcher believes that respondents' attitudes were also related to the levels of their self-efficacy in mathematics. Finally, the respondents' attitudes (self-confidence, value, enjoyment, and motivation) influenced students' mathematics performance. Meaning, when students have high confidence, gives a high value of math, enjoy the subject, and have high motivation, their self-efficacy will also be high. Having high self-efficacy could result in positive academic performance in mathematics. 


\section{INDEPENDENT VARIABLES}

\begin{tabular}{|l|}
\hline 1. STUDENT'S Socio- \\
Demographic PROFILE \\
1.1.Sex \\
1.2.Birth order \\
1.3.Parent's educational attainment \\
1.4.Parent's occupation \\
1.5.Monthly income \\
1.6.Daily allowance \\
1.7.Mathematics reading materials \\
available at home \\
1.8.Gadgets use in learning \\
mathematics \\
1.9. Time spent in studying \\
mathematics \\
1.10. Most liked subject and \\
disliked subject \\
2. STUDENT'S ATTITUDE \\
TOWARDS Mathematics \\
(Self-Confidence, Value, \\
Enjoyment, and Motivation) \\
3. STUDENT'S SELF- \\
EFFICACY TOWARDS \\
Mathematics
\end{tabular}

\section{DEPENDENT VARIABLE}

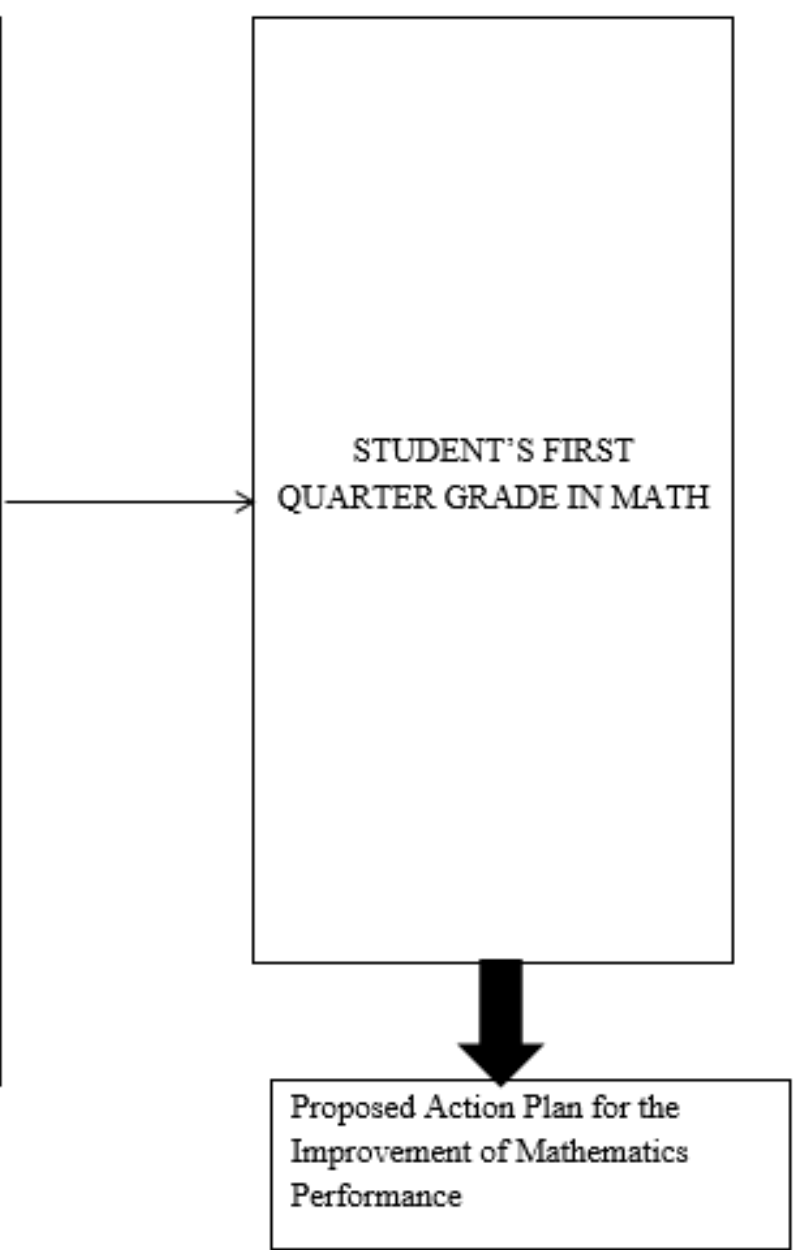

Fig.1: Research Paradigm

\section{PURPOSE OF THE RESEARCH}

This study aimed to assess the attitudes and selfefficacy of students toward Mathematics performance.

1. How may the socio-demographic profile of the respondents be described in terms of:

1.1. Sex ;

1.2. Birth order;

1.3. Parent's educational attainment;

1.4. Parent's occupation ;

1.5. Monthly income;

1.6. Daily allowance;

1.7. Mathematics reading materials available at home;

1.8. Gadgets use in learning mathematics;

1.9. Time spent in studying mathematics, and
1.10. Most liked the subject and disliked subject?

2. What is the level of performance of the respondents in math based on their first quarter grade?

3. What is the attitude of the respondents towards mathematics in terms of:

3.1 self-confidence;

3.2 value;

3.3 enjoyment, and

3.4 motivations?

4. What is the level of self-efficacy of the respondents towards math?

5. Is there a significant relationship between the profile of the respondents and their: 


\subsection{Attitudes; \\ 5.2 self-efficacy, and \\ 5.3 Mathematics performance?}

6. Is there a significant relationship between the respondents' attitudes and level of self-efficacy in Mathematics?

7. Is there a significant relationship between the attitudes of the respondents towards Mathematics and Mathematics performance?

8. Is there a significant relationship between respondents' level of self-efficacy towards math and Mathematics performance?

\section{METHODOLOGY}

This part discusses the research design, research locale, participants of the study, sampling design and research instruments, data gathering procedure, and statistical treatment of data.

\section{Research Design}

This study employed a descriptive - correlational research design to examine the student's profile, attitude, level of self-efficacy, and performance in mathematics of Grade 9 students in Dinalungan and Casiguran district for the school year 2019-2020.

Descriptive such as frequency, weighted mean, and percentages were used to present student's profile, which includes sex, birth order, parent's educational attainment, parent's occupation, monthly income, daily allowance, mathematics reading materials available at home, gadgets use in learning mathematics, time spent in studying mathematics, most liked the subject and disliked subjects. Specifically, it is a survey type. It is a type of research that is most appropriate in this study since an assessment survey is needed. The descriptive - correlation method of studies is best suited. As mentioned, the data were generated using a researcher-made and adapted questionnaire.

\section{Research Locale}

The study was conducted at secondary school in Dinalungan and Casiguran, Aurora. Mariano D. Marquez Memorial National High School and Juan C. Angara Memorial High School are located at Dinalungan, Aurora. Casiguran National High School, Lual National High School, Dibacong National High School, and Tinib-Calacuasan
Integrated School were located at Casiguran, Aurora. The researcher selected the research site because he was teaching at one of the said schools and had observed that mathematics attitudes and self-efficacy were factors of the problems of the students, and these somehow affected their academic performance. The researcher wanted to gather relevant information about the levels of students' attitudes and selfefficacy in mathematics for them, who were teaching mathematics subjects, making possible solutions in alleviating attitudes, and developing students' self-efficacy in mathematics. The researcher also considered accessibility.

\section{Instrumentation}

The Attitudes Toward Mathematics Inventory (ATMI) was initially developed by Tapia and Marsh (2004) in English. The inventory comprised of 49 items and constructed to cover six domains related to attitudes towards mathematics. These are confidence, anxiety, value, enjoyment, motivation, and parent/teacher expectations. The items were constructed using Likert-scale format, and the students respond to the statement on a five-point scale ranging from strongly agree (5), agree (4), neutral (3), disagree (2), and strongly disagree (1). Out of 49 questions, 12 items have negative wordings. According to the developers, these domains were considered due to the previous studies reported as essential factors.

The final version of the ATMI comprises 40 items with four subscales, namely, self-confidence (15 items), value (10 items), Enjoyment (10 items), and Motivation (5 items). The items in the questionnaire are appropriate for the present study since it focused on the attitudes of students towards math.

The questionnaire-checklist that aims to draw out proper responses to the objectives of this study will be constructed. This questionnaire - checklist made and adapted by the researcher and will be presented for analysis and checking by the research adviser to ensure the validity of responses it would elicit.

ATMI is a reliable instrument that demonstrates content and constructs validity. The instrument has a coefficient alpha of 0.97 with a standard error of measurement of 5.67. Item-to-total correlations indicate the right internal consistency. Principal component analysis with a varimax rotation resulted in a four-factor structure as the best fit for these items. (Tapia, Martha; Marsh, George E.,2000) 
There is evidence of content validity. The factor structure of the ATMI revised fits the domain of attitudes' towards mathematics. Anxiety and confidence, enjoyment, and motivation. (Tapia, Martha; Marsh, George E.,2000), However, since the questionnaire was already used in the previous study, the instrument is reliable and valid.

For the level of self-efficacy, the researcher based and adapted the questionnaire on the Mathematics SelfEfficacy and Anxiety Questionnaire (MSEAQ) by DIANA K. MAY (2006) in determining the students' levels of anxiety and self-efficacy in mathematics. Since the tool is for anxiety and self-efficacy, the researcher adopted only the self-efficacy tool because it is the only need.

The computed Cronbach's Alpha determined the internal consistency of the students' responses. For the students' responses on the level of their anxiety, the computed Cronbach's Alpha is 0.92 or $92 \%$, which means there is high internal consistency on the students' responses. For the students' responses on the level of their self-efficacy, the computed Cronbach's Alpha is 0.94 or $94 \%$, which means there is high internal consistency on the students' responses. As cited and used by Bondoc (2015).

The performance of the respondents will be measured using their grades for the first quarter examination.

\section{Data Gathering Procedure}

In gathering the data for this study, the researcher observed the following steps: First, the researcher was personally sent a letter seeking the approval on the conduct of the study to the office of the Schools Division Superintendent. The same procedure was made to the District Supervisor. A similar procedure was made to the school head of the school understudy.

The second was the administration and retrieval of the questionnaire. The researcher was asked permission from the school heads to distribute the questionnaire, administer, and conduct an interview with the respondents. Finally, collation and tabulation of data were made. The researcher was collated, tally, and tabulate all the information acquired from the respondents utilizing a five-point Likert scale, analyze and interpret the statistical results with the help of a statistician.

\section{RESULTS, ANALYSIS AND DISCUSSION}

It presents the findings, analysis, and interpretation of the data gathered through textual and tabular forms to answer the stated problems.

\section{Profile of the Respondents}

The profile of the respondents included sex, birth order, parents' educational attainment, parents' occupation, parents' monthly income, daily allowance, mathematics reading materials available at home, gadgets use in learning mathematics, and time spent studying mathematics and most liked and most disliked subject.

1.1 Sex. Figure 2 presents the sex distribution of the respondents. Two hundred sixty-seven junior high school students represented the study as respondents. Females outnumbered their male counterparts with 167 or $61.55 \%$, while males were 100 or $37.45 \%$.

This means that the gender split in Philippine education is still too unbalanced. Citing the data released by Functional Literacy, Education and Mass Media Survey (FLEMMS) conducted in 2008, the estimated 68 million Filipinos 10 years old and over in 2008, $95.6 \%$ are literate. The introductory literacy rate among females is $96.1 \%$, while 95.1\% among males. Further, the Net Enrolment Ratio in the public secondary level during the same school year was lesser than the elementary level. There was a more significant disparity between girls and boys in high school at 1.17 Gender Parity Index, which is equivalent to 117 girls in every 100 boys (www.pcw.gov.ph, 2012). 


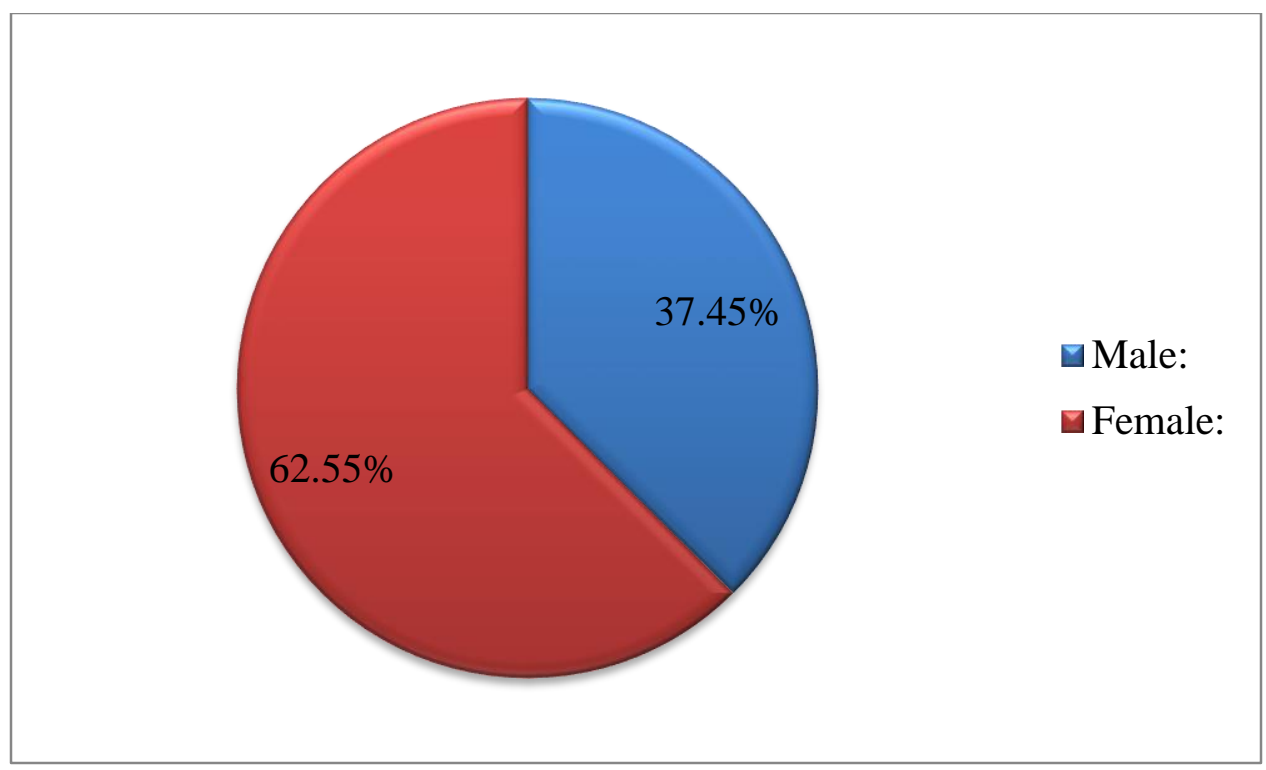

Fig.2: Sex of the Respondents

$$
\mathbf{N}=\mathbf{2 6 7}
$$

The finding was further supported by Gacayan (2013) in his study in Northern Aurora that the majority of the students were female compared to males. Therefore, I can say that no doubt, there is a significant gender disparity in Philippine education.

1.2 Birth Order. Figure 3 shows the respondents' child followed by first-born with $59(22.10 \%)$, second child (47 or $17.60 \%$ ), fourth (43 or $16.10 \%$ ), fifth ( 21 or $7.87 \%$ ), ninth (10 or $3.75 \%)$, sixth (9 or $3.37 \%)$, tenth (6 or $2.25 \%)$, and eight-born child was represented by only $1(0.37 \%)$ student. Noticeably, none of the respondents was a seventhborn child.

birth order. It revealed that $71(26.59 \%)$ were third-born

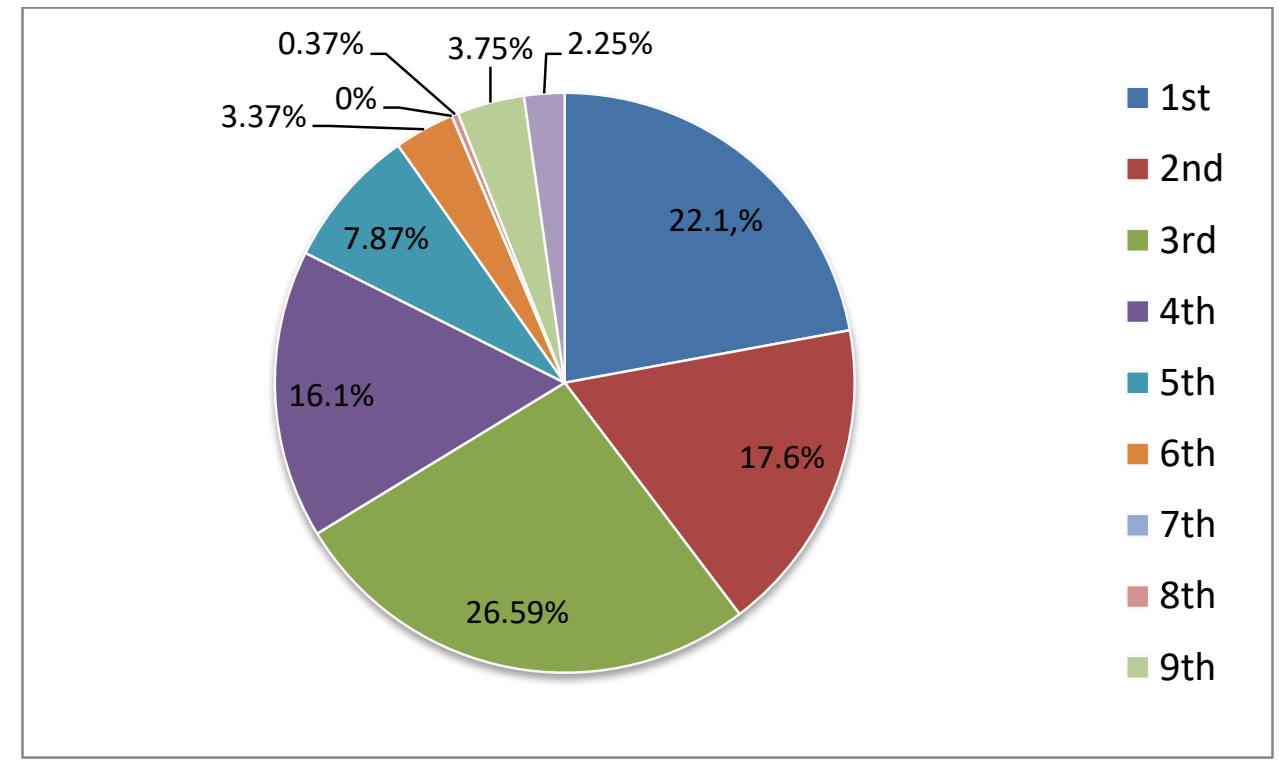

Fig.3: Birth Order of the Respondents

$$
\mathbf{N}=\mathbf{2 6 7}
$$


The impact of a person's birth order is often underestimated as a significant factor in identity formation. The environment at home impacts on child development, and birth order can influence how a child is treated by parents and siblings (Rocker, 2012).

According to Lehmann et al. (2012), several theories outline the potential channels through which birth order effects might occur. First, parents may face different time and financial constraints over their lifetime, preventing them from equalizing their resources and investments across children. On the one hand, if there are time and resources constraints, first-born and last-born children may benefit from their more significant share of resources than middleborn children. However, if parents' earnings tend to increase over their life cycle, later-born children may face more advantages than their earlier-born siblings. Second, changing the composition or parental characteristics may contribute to differing home environments across children of different birth orders. For example, later-born children may be more intellectually stimulated by growing up with older children and better-educated parents (Lehmann, 2012). Yet, if the level of intellectual stimulation at home is closely tied to parental time constraints, later-born children may be disadvantaged by being part of a larger family. Third, biological or physiological differences may also induce varying outcomes. Later-born children have older mothers, and older mothers are more likely to give birth to children of lower weight five and experience a greater number of complications during pregnancy and at birth. On the other hand, mothers may become better child caretakers as they gain experience with each child, and later-born children may benefit from better child-rearing practices.

First-born children are typically independent, trailblazers, with the propensity to be anxious or dominant. They have also been shown to be higher achievers, more conscientious, and more patient. Second-born siblings are more open to new experiences and demonstrate more rebellious tendencies (Rocker, 2012).

1.3 Parent's Educational Attainment. Table 2 shows the highest educational attainment of the respondents' parents. From 267 respondents, the majority of the father, 67 (25.09\%) were high school graduates, 53 (19.85\%) were high school undergraduate, and $39(14.61 \%)$ were unable to complete elementary. Twenty-seven $(10.11 \%)$ were college graduates, $23(8.61 \%)$ were elementary graduates, 22 $(8.24 \%)$ were college level, and 16 (5.99\%) undergo graduate studies.

The majority of mothers (79 or $29.59 \%$ ) were high school graduates, followed by 57 (21.35\%) high school level. There were 28 (10.49\% of the mother who was elementary level, and another $28(10.49 \%)$ were college graduates, 20 (7.49\%) were elementary graduates, $19(7.12 \%)$ were college level as well as $19(7.12 \%)$ with graduate studies degree. The remaining $17(6.37 \%)$ were with a vocational certificate.

Table 2. Parent's Educational Attainment

\begin{tabular}{lcccc}
\hline \multicolumn{1}{c}{ Educational Attainment } & \multicolumn{2}{c}{ Father } & \multicolumn{2}{c}{ Mother } \\
& Frequency & $\boldsymbol{\%}$ & Frequency & \% \\
\hline Elementary level & 39 & 14.61 & 28 & 10.49 \\
Elementary graduate, & 23 & 8.61 & 20 & 7.49 \\
High school level & 53 & 19.85 & 57 & 21.35 \\
High school graduate & 67 & 25.09 & 79 & 29.59 \\
Vocational certificate & 20 & 7.49 & 17 & 6.37 \\
College level & 22 & 8.24 & 19 & 7.12 \\
College graduate & 27 & 10.11 & 28 & 10.49 \\
Graduate studies & 16 & 5.99 & 19 & 7.12 \\
\hline & Total & $\mathbf{1 0 0}$ & Total & $\mathbf{1 0 0}$ \\
\hline
\end{tabular}

1.3 Parent's Occupation. Table 3 presents the occupation of the respondent's parents. Out of 267 respondents, $138(51.69 \%)$ reflected farming as their father's occupation, $66(24.72 \%)$ were self-employed, $50(18.73 \%)$ 
were private employees and 13 (4.87\%) government employee.

As of the mother's occupation, 164 (61.42\%) were housewives, $52(19.48 \%)$ were private employees, while 32
(11.99\%) were government employees. Fifteen of them, however, were recorded as self-employed while $4(1.50 \%)$ were farmers.

Table 3. Parent's Occupation

\begin{tabular}{lcccc}
\hline \multicolumn{1}{c}{ Occupation } & \multicolumn{2}{c}{ Mother } & \multicolumn{2}{c}{ Father } \\
Housewife & Frequency & $\mathbf{\%}$ & Frequency & $\mathbf{\%}$ \\
\cline { 2 - 5 } Government employee & 164 & 61.42 & & \\
Private employee & 32 & 11.99 & 13 & 4.87 \\
Self-employed & 52 & 19.48 & 50 & 18.73 \\
Farmer & 15 & 5.62 & 66 & 24.72 \\
Total & 4 & 1.50 & 138 & 51.69 \\
\hline
\end{tabular}

The combined findings of parents' occupation showed that most of them were farmers and housewives. This revealed the findings that most of them were high school graduates. Thus, the only job that fits them was according to their educational attainment. On the other hand, Children felt secure with their family if their needs are being provided. The child will not think anymore about how their needs in school and in-home will be provided because their parents' occupation can already provide their needs Gacayan (2013). Moreover, Pangeni (2009) suggested that parents who are educated to a higher level have greater access to a combination of economic and social resources that can be used to help children succeed in schools.

Lopez et al. (2009) revealed that the parents' job significantly affects the performance of the students. Parents with a permanent job have children who performed best in school.
1.4 Parent's Monthly Income. Figure 4 shows the monthly family income of the respondents. Of the 267 respondents, there were 182 or $68.16 \%$ among respondent's parents with a monthly income of below PHP. Ten thousand followed by 36 or $13.48 \%$ of the respondents with monthly income ranging from $\mathrm{PhP} .10000$ to $\mathrm{PhP} .15$, 000. There were 15 or $5.62 \%$ of the respondents reflected their parent's income amounting to PHP $16,000-20,000$ while 14 or $5.24 \%$ were earning a monthly income of $\mathrm{PhP} 21000-25$, 000 .

It can be noticed that 10 or $3.75 \%$ of the respondents have a monthly income of $\mathrm{PhP} 41000$ and above, 8 or $3.00 \%$ were earning PHP $26000-30,000$, and 2 or $0.75 \%$ were earning PHP 31, $000-40,000$. They are those who hold key positions either in government or private agencies and owners of business establishments. 


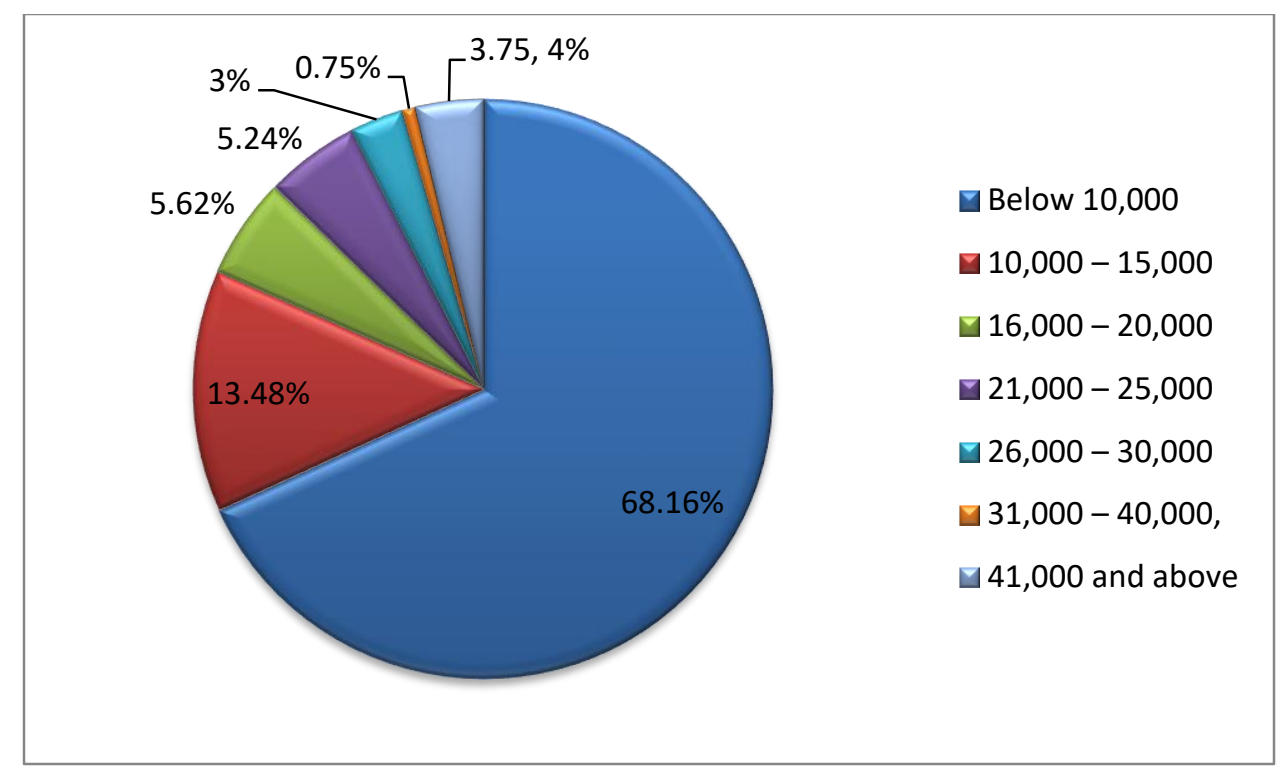

Fig.4: Monthly Family Income

$\mathrm{N}=267$

1.6 Daily Allowance. Figure 5 shows the respondents' daily allowance. Of the 267 respondents, most (109 or $40.82 \%)$ of the respondents indicated their daily allowance amounting to $11-20$ pesos followed by 49 or $18.35 \%$ with daily allowance amounting to $41-50$ pesos while 39 or $14.61 \%$ with 21 - 30 pesos daily allowance. Thirty-eight $(14.23 \%)$ have a daily allowance amounting to 61 pesos and above, while 14 or $5.24 \%$ have a daily allowance of below 10 pesos, and 4 or $1.50 \%$ have their daily allowance of $51-60$ pesos. It can be noticed that most of the respondents had a low daily allowance. Adzido (2016) stated that being in low socioeconomic status in terms of reasonable money allowance is not an excuse for poor performance. On the other hand, Dorkpah (2016) found out that families with higher socioeconomic status may improve students' performance and achieve better academic performance.

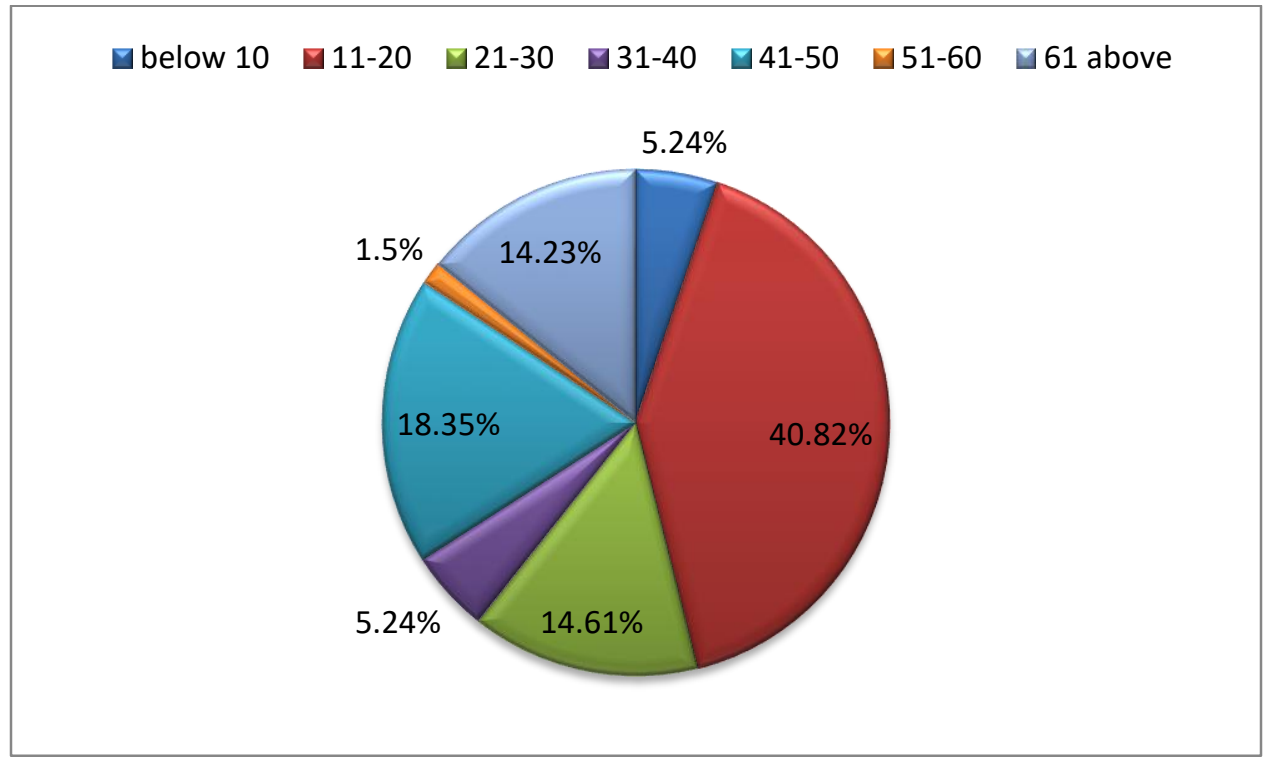

Fig.5: Daily Allowance of the Respondents

$$
\mathrm{N}=267
$$




\subsection{Mathematics Reading Materials Available at}

Home. Figure 6 shows the respondents' available math reading materials at home. Out of 267 respondents, the majority (162 or $60.67 \%$ ) have math books at home, which is common math reading materials followed by math textbook with 84 or $31.46 \%$ of the respondents, while 17 or $6.37 \%$ of them have math dictionary which they can use to learn math. However, 4 or $1.50 \%$ of the respondents do not have any reading materials for learning math at home. It can be noticed that most of the respondents have a math book at home. This implies that most of the respondents have more instructional reading materials at home as it serves as an integral part of learning.

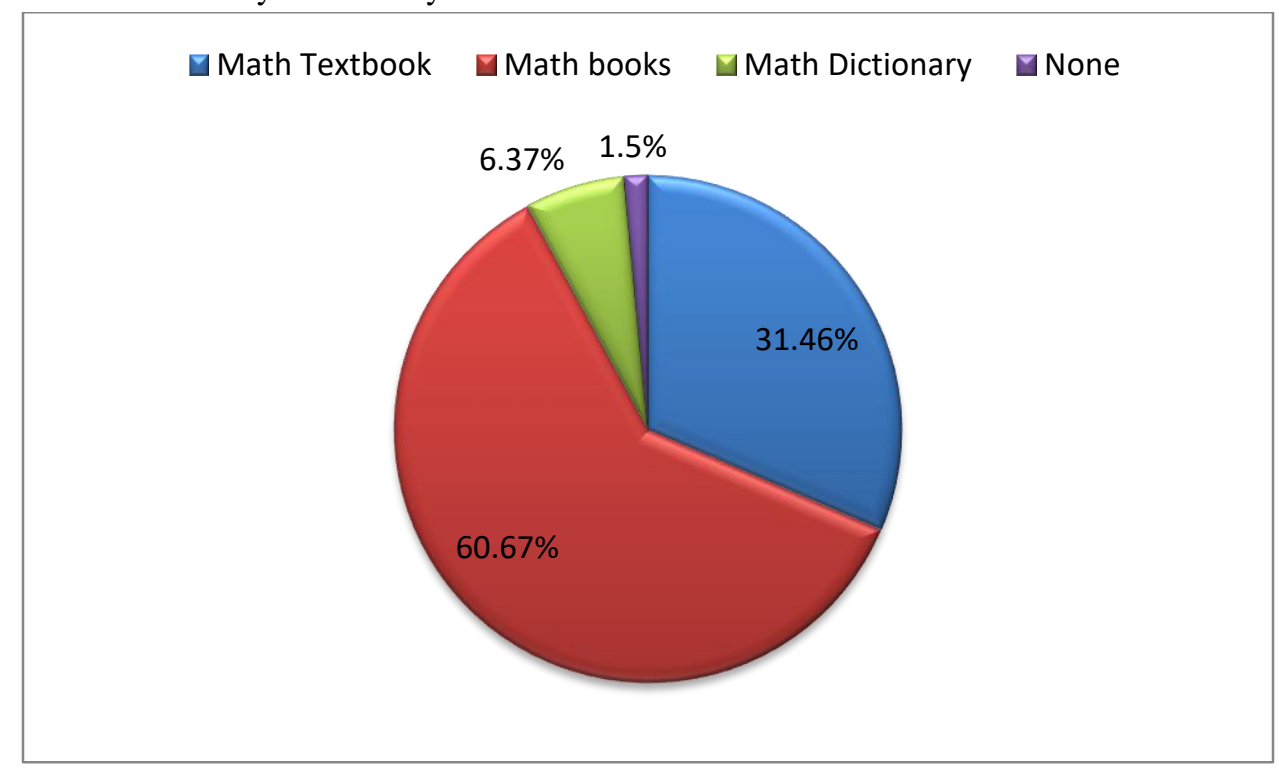

Fig.6: Mathematics Reading Materials Available at Home

$\mathrm{N}=267$

Moreover, based on the Children's Literacy Foundation (CLIF), home learners must be allowed to read their math learning materials. Once the environment is created for a learner who chooses what he wants to read with proper guidance, he is more motivated and more tendencies for math literacy development. Likewise, teachers believed that allowing the learners to read math books and practice what he reads guided with scaffolding increases enjoyment, confidence, and motivation (McDougall 2016).

1.8 Gadgets used in Learning Math. Table 4 shows the respondents' gadgets use in learning mathematics. Of the 267 respondents, the majority or (156) of the respondents used their cellphones in learning math, while 144 used a calculator, 11 used laptops, and 8 used desktop computers.

Table 4. Gadgets

\begin{tabular}{lcc}
\hline Gadgets use in learning mathematics & Frequency & Rank \\
\cline { 2 - 3 } Cell phone & 156 & 1 \\
Calculator & 144 & 2 \\
computer desktop & 8 & 4 \\
Laptop & 11 & 3 \\
\hline
\end{tabular}

*multiple responses 
Results revealed that most students utilized their cellphones in text messaging, chat, games, movie watching, and video chats but also, they used it as a tool in learning math. Cellphones or Cellular phones nowadays have different applications that can be used in learning different subject areas. With the aid of the internet, cellphone users can browse different topics of their interest, helping them learn. This implies that the respondents were using either cell phone or calculator in learning math subjects.

1.9 Time they were Spent in Studying Math. Figure 7 shows the respondents' number of hours spent studying math. Out of 291 respondents, time allocation is essential in all aspects of learning. The majority of the respondents spend at least 1-hour learning math (191 or $71.54 \%$ ), while 51 or $19.10 \%$ spent 30 minutes and below, and 15 or $5.62 \%$ spent 2 hours learning math. Few of them spent more than two hours of learning math. As shown in the table, 4 or $1.50 \%$ spent 3 hours and 4 hours respectively. Interestingly, two $(0.75 \%)$ of the respondents spent 5 hours and above in learning math.

The result implies that most of the respondents were allocating at least 1 hour of their learning math subject. It also means that the respondents have a few time in studying Mathematics at home.

This implies that most of the respondents had lesser time for studying math at home. Gbore (2009) found out that study time attitudes affect a strong relationship with the academic performance of students, while Adeyemo (2009) concluded that the students' academic achievement was the outcome of a combination of the study of time behavior and other factors in any course of study.

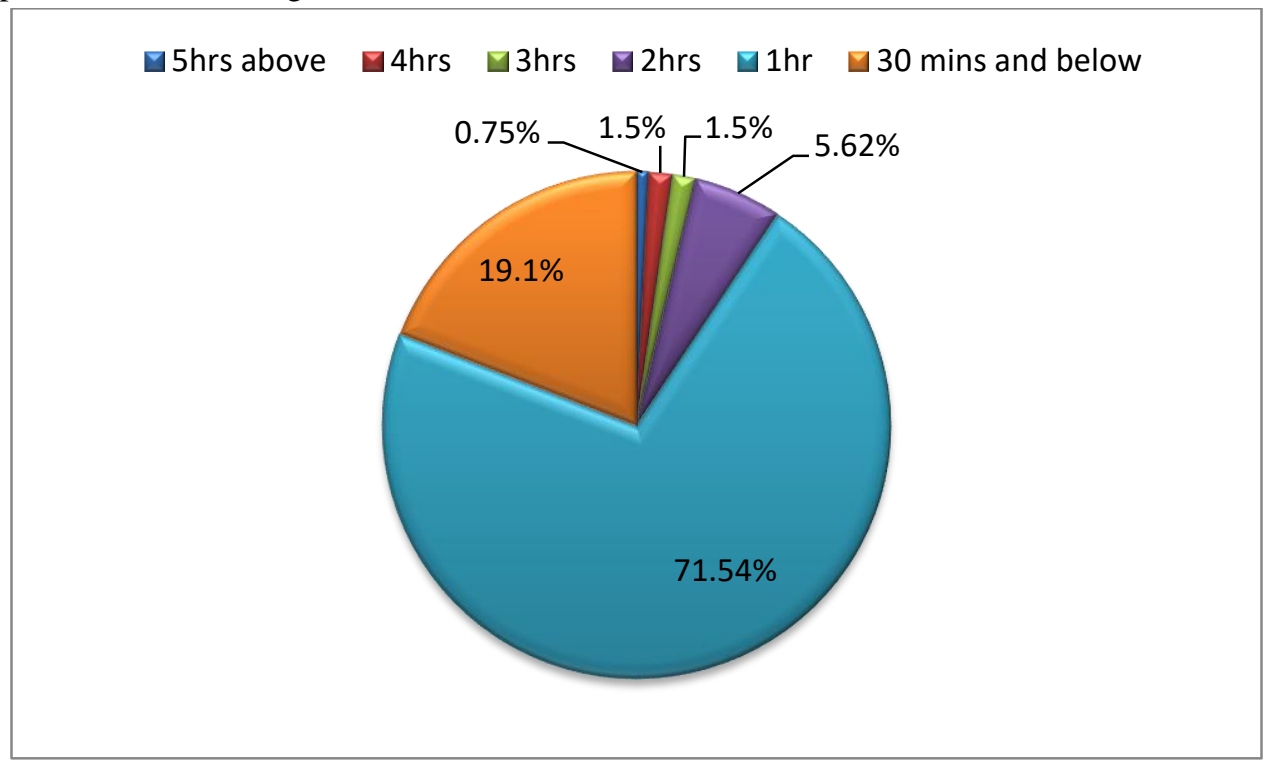

Fig.7: Time Spent in Studying Math.

$\mathrm{N}=267$

1.10 Most Liked and Disliked Subject. Table 5 shows the respondents' most liked and disliked subject. Out of eight subjects in junior high school, math was the most liked subject by 71 or $26.59 \%$ of the respondents. Filipino follows with 36 or $13.48 \%$, both English and Science with 35 or $13.11 \%$, MAPEH (34 or 12.73\%), Araling Panlipunan (33 or $12.36 \%$ ), TLE (15 or $5.62 \%$ ), and ESP (8 or $3.00 \%$ ). Interestingly, few of the respondents liked ESP or Edukasyon sa Pagpapakatao (Values Education). This implies that some of the respondents were not interested in this subject even though it focusses on the development of good manners to become a good citizen of society.

In terms of most disliked subject, from 267 respondents, $25.47 \%$ of the respondents indicated that they disliked math, $17.23 \%$ disliked science, $15.73 \%$ disliked English, $12.36 \%$ disliked Araling Panlipunan, and 9.36\% disliked TLE subject. 
Table 5. Most Liked Subject and Most Disliked Subject

\begin{tabular}{lcccc}
\hline \multirow{2}{*}{ Subjects } & \multicolumn{2}{c}{ Most Liked Subject } & \multicolumn{2}{c}{ Most Disliked Subject } \\
Frequency & Frequency & \% \\
\cline { 2 - 5 } English & 35 & 13.11 & 42 & 15.73 \\
Science & 35 & 13.11 & 46 & 17.23 \\
Math & 71 & 26.59 & 68 & 25.47 \\
Filipino & 36 & 13.48 & 8 & 3.00 \\
Araling Panlipunan & 33 & 12.36 & 33 & 12.36 \\
TLE & 15 & 5.62 & 25 & 9.36 \\
MAPEH & 34 & 12.73 & 17 & 6.37 \\
ESP & 8 & 3.00 & 8 & 3.00 \\
None & & & 20 & 7.49 \\
\hline Total & $\mathbf{2 6 7}$ & $\mathbf{1 0 0}$ & $\mathbf{2 6 7}$ & $\mathbf{1 0 0}$ \\
\hline
\end{tabular}

The findings showed that the majority of the respondents liked the math subject. However, a large number of them also indicated that they disliked math subjects. This implies that some of the respondents favored math, and some showed no interest in the subject. This further implies that the respondents varied in terms of the favorite subject and less preferred subject. They are taking all the subjects as a requirement for the completion of their curricula.

\section{Respondents' First Quarter Grade in Math.}

The table shows the respondents' first-quarter grade in Mathematics subject. The mean grade of the respondents in Mathematics performance was 82.83 , which was verbally

Table 6. Frequency distribution of respondents' first-quarter grade in Math

\begin{tabular}{cccc}
\hline First Quarter Grade & Frequency & \% & Verbal Description \\
\hline $95-100$ & 432 & 1.50 & Excellent \\
$90-94$ & 3457 & 12.73 & Approaching Excellence \\
$85-89$ & 7862 & 29.21 & Proficient \\
$80-84$ & 6278 & 23.22 & Approaching Proficiency \\
$75-79$ & 5734 & 21.35 & Developing \\
$74-$ below & 324 & 11.99 & Beginning \\
Total & $\mathbf{2 6 7}$ & $\mathbf{1 0 0}$ & \\
\hline Mean First Quarter Grade & $\mathbf{8 2 . 8 3}$ & & Approaching Proficiency \\
\hline
\end{tabular}

interpreted as approaching proficiency. Seventy-eight of the respondents, which makes up the majority with $29.21 \%$, got an average grade of $85-89$ proficient in math. It was followed by 62 respondents $(23.22 \%)$ with an average grade of $80-84$, which was verbally interpreted as approaching proficiency, 57 respondents (21.35\%) with $75-79$ average grades, and 34 respondents (12.73\%) who got an average grade of $90-94$. However, 32 (11.99\%) of the respondents got a failing grade of 74 and below. A few (4 or 1.50\%) of them got the highest grade of $95-100$. 
The result implies that the respondents perform differently in their math subjects, as reflected in their first-quarter grades. The majority of the performance of the respondents in mathematics were proficient as verbal interpreted. This implies that most of the respondents attained a proficiency level, according to DepEd Order No, 30, s. In 2012, these learners could independently show the competencies and do the tasks related to them as they reached the proficiency level. Students are now ready to apply their skills through gained fundamental skills.

On the other hand, several researchers, including the one conducted by Garoma (2016), stated that most students had low mathematical achievement. Kosha and Gupta (2010) pointed out that the performance of the students may be attributed to several interactions of critical factors associated with students, the schools, and the curriculum. These factors may also be the reason for the different performance of students in public secondary school.

\section{Respondents' Attitudes towards Mathematics}

Tables 7, 8, 9, and 10 present the respondents' attitudes in Mathematics in terms of self-confidence, value, and enjoyment and motivation component.

\subsection{Respondents' Self-confidence towards}

\section{Mathematics}

It shows that the overall weighted mean was 3.04, which was verbally interpreted as "neutral". This meant that respondents had moderately high of attitudes on when asked about their self-confidence in Math subject. The findings showed that most of the respondents had moderately high self-confidence, which showed a positive attitude. They tend to believe that their valued effort in increasing their mathematical ability and considering if mathematics as useful in their daily lives will help them in their future care

Table 7. Respondents' Attitudes towards Self-Confidence in Math

\begin{tabular}{|c|c|c|c|c|}
\hline & Self-Confidence & WM & VD & Indication \\
\hline 1 & Mathematics does not scare me at all. & 3.15 & Neutral & Moderately High \\
\hline 2 & I have a lot of self-confidence when it comes to mathematics & 3.18 & Neutral & Moderately High \\
\hline 3 & I can do mathematics experiments without too much difficulty. & 2.96 & Neutral & Moderately High \\
\hline 4 & I expect to do well in any mathematics class I take. & 3.01 & Neutral & Moderately High \\
\hline 5 & I am always confused about my mathematics class. & 2.91 & Neutral & Moderately High \\
\hline 6 & I feel a sense of insecurity when attempting mathematics. & 2.83 & Neutral & Moderately High \\
\hline 7 & I learn mathematics quickly. & 3.00 & Neutral & Moderately High \\
\hline 8 & I am confident that I could learn advanced mathematics. & 3.17 & Neutral & Moderately High \\
\hline 9 & I have usually enjoyed studying mathematics at school. & 3.42 & Agree & High \\
\hline 10 & Mathematics is dull and boring. & 2.39 & Disagree & Moderately High \\
\hline 11 & I like to do new experiments in mathematics. & 3.32 & Neutral & Moderately High \\
\hline 12 & $\begin{array}{l}\text { I would prefer to experiment with mathematics than to write an } \\
\text { essay. }\end{array}$ & 2.97 & Neutral & Moderately High \\
\hline 13 & I would like to avoid using mathematics in college. & 2.84 & Neutral & Moderately High \\
\hline 14 & I like mathematics. & 3.25 & Neutral & Moderately High \\
\hline 15 & I believe I am good at mathematics experiments. & 3.16 & Neutral & Moderately High \\
\hline & Overall Weighted Mean & 3.04 & Neutral & Moderately High \\
\hline$\overline{\text { Lege }}$ & Verbal Description & & & \\
\hline & Strongly Agree (SA) & & & \\
\hline & $4.20-3.41$ & & & \\
\hline
\end{tabular}

ISSN: $2456-7620$ 

$3.40-2.61$
Neutral (N)
$2.60-1.81$
Disagree (D)
Strongly Disagree (SD)

\section{Moderately high}
Low
$1.80-1.00$

Results also revealed that there were respondents who showed disagreement that math is dull and boring. This implies that most of the respondents have high selfconfidence and attitude towards mathematics since they believe that mathematics would help them in their future careers. This indicates that a healthy attitude towards mathematics can nurture self-confidence among students. The enjoyment of the respondents while studying mathematics and the likeness of doing mathematics experiments were showed how students were willing to learn mathematics lessons. According to the study of Van der Bergh (2013), students with high self-confidence believe in their abilities that they can be successful in learning mathematics, thus overcoming the fear of failing. These are ready to take mathematical challenges, which in turn increase their academic achievement; otherwise, students with low self-confidence do not believe in themselves, thus tend to avoid taking mathematics challenges (Adelson \& McCoach, 2011). Moreover, Martino (2014) mentioned that if the self- confidence toward mathematics is low, it will defeat the purpose of learning in mathematics. Thus, self-confidence toward mathematics was an essential part of success in mathematics achievement.

\subsection{Respondents' Value for Mathematics.}

It was shown that the respondents have high value towards math, as shown in the overall weighted mean of 3.54. This means that the respondents have a high value in learning math. This further implies that the respondents value the usefulness of mathematics in everyday life and to the world in general. However, some respondents show moderately high value towards math when they indicated that, "I get a great deal of satisfaction out of mathematics experiments" with a weighted mean of 3,24; "Mathematics is one of my most dreaded subjects" with a weighted mean of 2.98; and "My mind goes blank, and I am unable to think clearly when studying mathematics" with a weighted mean of 2.89 .

Table 8. Respondents' Attitude towards Value of Mathematics

\begin{tabular}{|c|c|c|c|c|}
\hline & Value & WM & $\begin{array}{c}\text { Verbal } \\
\text { Description }\end{array}$ & Indication \\
\hline 1 & Mathematics is a very worthwhile and necessary subject. & 3.45 & Agree & High \\
\hline 2 & I want to develop my mathematics skills. & 3.97 & Agree & High \\
\hline 3 & I get a great deal of satisfaction out of mathematics experiments. & 3.24 & Neutral & Moderately high \\
\hline 4 & Mathematics helps develop the mind and teaches a person to think. & 3.84 & Agree & High \\
\hline 5 & Mathematics is vital in everyday life. & 3.95 & Agree & High \\
\hline 6 & $\begin{array}{l}\text { Mathematics is one of the most important subjects for people to } \\
\text { study. }\end{array}$ & 3.82 & Agree & High \\
\hline 7 & $\begin{array}{l}\text { High school mathematics courses would be beneficial no matter what } \\
\text { I decide to study. }\end{array}$ & 3.78 & Agree & High \\
\hline 8 & I can think of many ways that I use mathematics outside of school. & 3.46 & Agree & High \\
\hline 9 & Mathematics is one of my most dreaded subjects. & 2.98 & Neutral & Moderately High \\
\hline \multirow[t]{2}{*}{10} & $\begin{array}{l}\text { My mind goes blank, and I am unable to think clearly when studying } \\
\text { mathematics. }\end{array}$ & 2.89 & Neutral & Moderately High \\
\hline & OWM & 3.54 & Agree & High \\
\hline \multirow[t]{2}{*}{ Leg } & Verbal Description & & & \\
\hline & Strongly Agree (SA) & & & \\
\hline
\end{tabular}

ISSN: 2456-7620 


$\begin{array}{lll}4.20-3.41 & \text { Agree (A) } & \text { High } \\ 3.40-2.61 & \text { Neutral (N) } & \text { Moderately high } \\ 2.60-1.81 & \text { Disagree (D) } & \text { Low } \\ 1.80-1.00 & \text { Strongly Disagree (SD) } & \text { Very low }\end{array}$

The findings showed that most of the respondents had a high value of the usefulness of mathematics, especially their eagerness or willingness to develop their mathematical skills as it is essential in their daily life.

According to Getahun et al. (2016), the high value of math may emanate from the students' awareness of the emphasis given to science disciplines in the education system, and the essential role math plays in the disciplines. Likewise, respondents of the present study showed a high value of math. Furthermore, the study of Sangkap (2010) showed positive beliefs that Filipino students valued effort in increasing one's mathematical ability and considered mathematics as useful in their daily lives.

\subsection{Respondents' Enjoyment of Mathematics.}

As presented in Table 9, the overall weighted mean is 3.42 , interpreted as high. This means that the respondents have high enjoyment in learning math subjects. The finding

showed that respondents were enjoyed their mathematics subject because they believed that studying mathematics trained them on how to solve the problem in some other areas. After all, it developed critical thinking skills and problem-solving skills, which were the main objectives of the mathematics curriculum of the Department of Education. It also shows that, knowing mathematics how hard, the respondents believed that advanced studying is useful to cope with the lessons in mathematics. According to the study of Villaver (2014), Filipino students could not go beyond simple recall. They could not fully comprehend the questions, thus leading to a wrong answer. Mathematics performance, as measured by the National Achievement Test (NAT) result is below the 50\% required by DepEd. In 2009. It implies that the lessons in mathematics were not quickly learned by the students inside the classroom; instead, they need to follow up learning at home through homework or advanced studying in their mathematics lessons.

Table 9. Respondents' Enjoyment Of Mathematics

\begin{tabular}{|c|c|c|c|c|}
\hline & Enjoyment & $\mathbf{W M}$ & $\begin{array}{c}\text { Verbal } \\
\text { Descriptio } \\
\mathbf{n}\end{array}$ & Indication \\
\hline 1 & I am happier in a mathematics class than in any other class. & 3.25 & Neutral & Moderately high \\
\hline 2 & Mathematics is a fascinating subject. & 3.45 & Agree & High \\
\hline 3 & I am willing to take more than the required amount of mathematics. & 3.26 & Neutral & Moderately high \\
\hline 4 & I plan to take as much mathematics as I can during my education. & 3.34 & Neutral & Moderately high \\
\hline 5 & The challenge of mathematics appeals to me. & 3.45 & Agree & High \\
\hline 6 & I think studying advanced mathematics is useful. & 3.68 & Agree & High \\
\hline 7 & $\begin{array}{l}\text { I believe studying mathematics helps me with problem-solving in } \\
\text { other areas. }\end{array}$ & 3.72 & Agree & High \\
\hline 8 & $\begin{array}{l}\text { I am comfortable expressing my ideas on how to look for solutions } \\
\text { to a problematic mathematics experiment. }\end{array}$ & 3.31 & Neutral & Moderately high \\
\hline 9 & I am comfortable answering questions in mathematics class. & 3.24 & Neutral & Moderately high \\
\hline \multirow[t]{2}{*}{10} & $\begin{array}{l}\text { A strong mathematics background could help me in my } \\
\text { professional life. }\end{array}$ & 3.49 & Agree & High \\
\hline & OWM & 3.42 & Agree & High \\
\hline
\end{tabular}




$\begin{array}{lll}5.00-4.21 & \text { Strongly Agree (SA) } & \text { Very high } \\ 4.20-3.41 & \text { Agree (A) } & \text { High } \\ 3.40-2.61 & \text { Neutral (N) } & \text { Moderately high } \\ 2.60-1.81 & \text { Disagree (D) } & \text { Low } \\ 1.80-1.00 & \text { Strongly Disagree (SD) } & \text { Very low }\end{array}$

\section{Mathematics.}

\subsection{Respondents' Motivation towards}

Table 10 presents the motivation of the respondents in learning mathematics. It shows that most respondents have moderately high motivation based on the overall weighted mean of 2.90. This implies that the respondents have moderately high motivation in learning mathematics

The results showed that most of the respondents had moderately high motivation when they feel nervous and uncomfortable in studying mathematics. This implies that respondents have negative motivation in mathematics subjects. They feel nervous that leads to uncomfortable in studying mathematics. Since the majority of respondents of this study was female, it indicates that female respondents have less motivation in mathematics subject compared to male. This result was supported by the findings of Elci (2017) that statistically significant differences were found in favor of attitude male towards mathematics. Moreover, the findings of Veloo et al. (2015) reported that there is a gender difference in students' attitudes towards mathematics. Male students are more interested in mathematics than the female.

Table 10. Respondents' Motivation Towards Mathematics

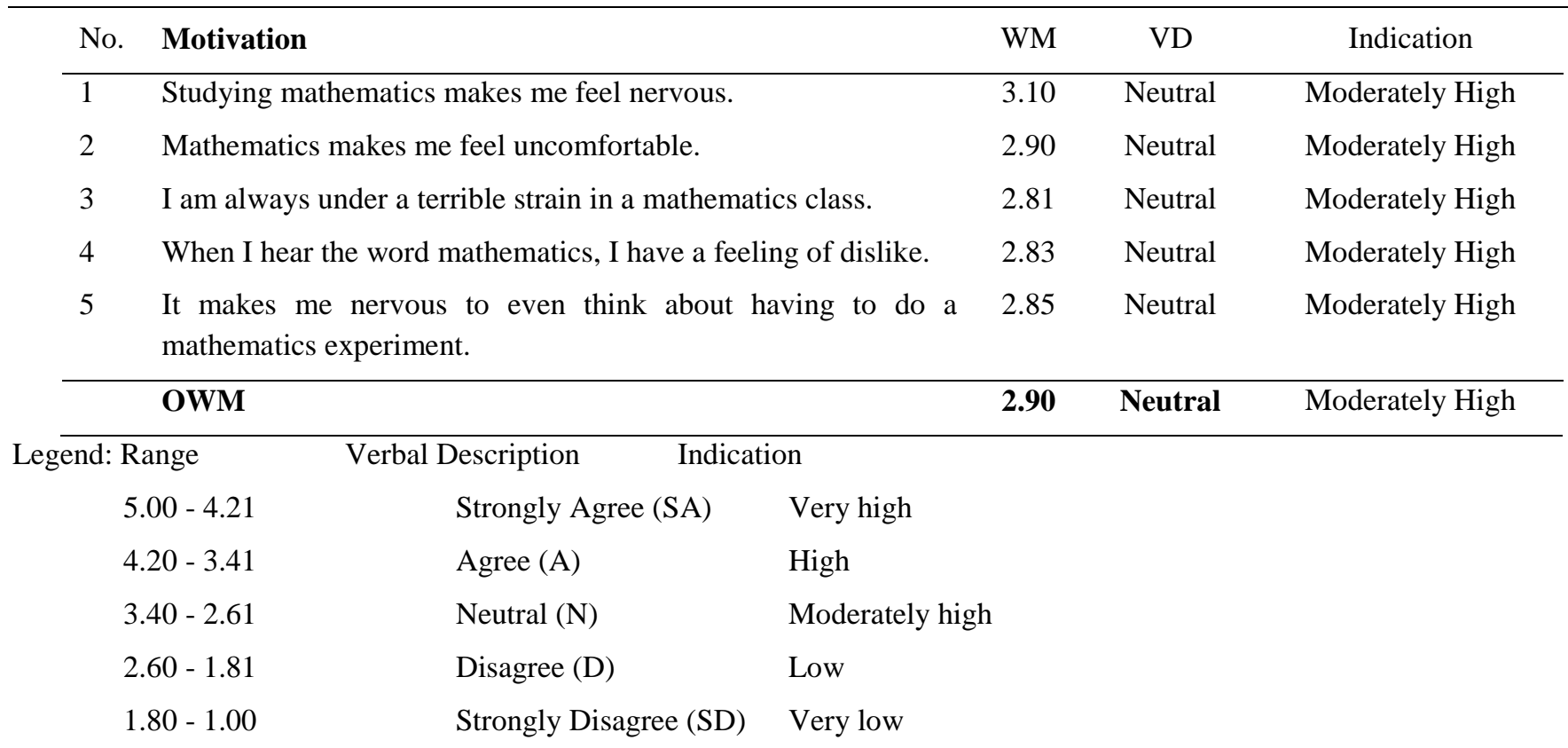

Based on the study of Gacayan (2013), the effectiveness of motivators affects so many student choices for school work. They remain engaged depending on the multi-factors of age, curriculum, vision, instructional strategies, tasks, learning context, and roles of the school, home, teacher, and students. Engaged students are observed to be intrinsically motivated.
They are more influenced by success in school, which they attribute to well-planned lessons, structured classrooms, engaging class presentations and discussions, and motivated teachers. 


\section{Self-efficacy of the Respondents Towards Mathematics}

Table 11 presents the respondents' level of selfefficacy in Mathematics. As shown in the table, the overall weighted mean was 3.25 , verbally interpreted as moderately high. This means that the respondents have a moderately high level of self-efficacy in mathematics. This implies that most of the respondents had moderately high self-beliefs towards mathematics because they believe they can use it in their future careers. They further believe that having a positive self-confidence towards mathematics will help them in their future endeavors. It can also be noticed that respondents felt confident enough to ask questions in mathematics class. It indicates that students were interested and more willing to learn those lessons which didn't understand, meaning students were actively participated in the teachers' and students' learning process.

This supported the findings of Prakash (2011) as stated that our drives, motives and emotions govern our interests, but mostly our instincts. In another article entitled "Creating an Interest in Learning Science", Paris and Turner (as cited in Keiff, 2009) said that interest plays a vital role in motivating students to study. If the learner has an interest in the subject matter, it is more likely that the learner will engage in a good study habit that will help the student expand the knowledge at hand. Realizing the importance of mathematics in their lives would help the respondents be more motivated to learn mathematics concepts.

Table 11. Respondents' Self-Efficacy Towards Mathematics

\begin{tabular}{llccc}
\hline & Self-efficacy & WM & VD & Indication \\
\hline 1 & I feel confident enough to ask questions in my mathematics class & 3.33 & Neutral & Moderately High \\
2 & I believe I can do well on a mathematics test. & 3.27 & Neutral & Moderately High \\
3 & $\begin{array}{l}\text { I believe I can complete all the assignments in a mathematics } \\
\text { course. }\end{array}$ & 3.13 & Neutral & Moderately High \\
4 & I believe I am the kind of person who is good at mathematics. & 3.11 & Neutral & Moderately High \\
5 & I believe I will be able to use mathematics in my future career & 3.54 & Agree & High \\
& when needed. & & & Moderately High \\
7 & I believe I can understand the content in a mathematics course. & 3.30 & Neutral & Moderately High \\
8 & I believe I can get an "A" when I am in a mathematics course. & 3.15 & Neutral & Moderately High \\
9 & I believe I can learn well in a mathematics course. & 3.36 & Neutral & I feel confident when taking a mathematics test. \\
10 & I believe I am the type of person who can do mathematics. & 3.28 & Neutral & Moderately High \\
11 & I feel that I will be able to do well in future mathematics courses. & 3.28 & Neutral & Moderately High \\
12 & I believe I can do the mathematics in a mathematics course. & 3.19 & Neutral & Moderately High \\
13 & I believe I can think like a mathematician. & 3.02 & Neutral & Moderately High \\
14 & I feel confident when using mathematics outside of school. & 3.30 & Neutral & Moderately High \\
\hline
\end{tabular}

Legend: Range

$5.00-4.21$

$4.20-3.41$

$3.40-2.61$

$2.60-1.81$

$1.80-1.00$
Verbal Description

Strongly Agree (SA)

Agree (A)

Neutral (N)

Disagree (D)

Strongly Disagree (SD)
Indication

Very high

High

Moderately high

Low

Very low

ISSN: 2456-7620 
Furthermore, Kundu and Ghose (2016), in their study, shows that self-efficacy in mathematics is strongly influenced by the attitude towards the subject. It was further supported by Altura and Yacizi (2010) that students with a positive attitude to mathematics see mathematics as a friendly tool or a challenge. This boosts their confidence and thus increases their self-efficacy.

\section{Relationship of Respondents' Profile and their Self- Confidence, Value, Enjoyment, and Motivation in Mathematics}

Table 12 presents the relationship among profile variables of the respondents and their self-confidence, value, enjoyment, and motivation in mathematics.

It can be noted that respondents' sex was significantly related to self-confidence component $(r=-.130$, $\mathrm{p}<0.05)$. Thus, the null hypothesis is rejected. The negative correlation indicates that male respondents have a high level of self-confidence than the female level of self-confidence. It implied that Result supported by the study of Elci (2017) that statistically significant differences were found in favor of attitude male towards mathematics. Moreover, the findings of Veloo et al. (2015) reported that there is a gender difference in students' attitudes towards mathematics. Male students are more interested in mathematics than the female.

Parents' education was significantly related to how respondents' value mathematics $(\mathrm{r}=.192, \mathrm{p}<.01)$ and $(\mathrm{r}=$ $.199, \mathrm{p}<.01)$. Thus, the null hypothesis was rejected. This implies that parents' educational attainment was a great impact on attitude value towards mathematics. It implied that most parents of the respondents were work-oriented. It means that parents valued how education is important to their children because they don't want their children to experience the life of being a farmer. Although being a farmer is a great job, but it requires more physical difficulties.

On the other hand, based on their hardships of being a farmer, it serves as the motivation for their children to pursue their career and give more focus on their study. The result was supported by the findings of Alokan (2013) that educational attainment played an essential role in influencing the level of academic achievement of their children. However, it can also serve as their motivation to achieve their dreams. Moreover, the findings of Gacayan (2013) when he found out that parental educational attainment had significant effect on child's performance.

Significant relationship was also found between mothers' occupation and respondents' value of mathematics $(\mathrm{r}=.151, \mathrm{p}<.01)$. Thus, the null hypothesis is rejected. This implies that respondents' mother's occupation was significantly related to the respondents' value in mathematics. It implies that mothers' occupation has a big impact on valuing mathematics because mothers were primarily observed what the family needs. Most of the respondents' mother occupation were housewives, It implies mothers easily monitor the needs of their children in terms of their learning, and they influenced their children to study and value those learning that they acquired in school. It was proven that if the mother focused on their children, then their children will perform well their academic performance. This finding concurs with Recber (2018) that a mother's occupation is significant in the achievement of students and is correlated with academic achievement while the father's occupation does not.

Table 12. Relationship of Respondents' Profile and Attitudes

\begin{tabular}{|c|c|c|c|c|c|c|c|c|c|c|c|c|}
\hline \multirow{3}{*}{ Profile } & \multicolumn{12}{|c|}{ Attitudes } \\
\hline & $\begin{array}{c}\text { Self } \\
\text { Confid } \\
\text { ence }\end{array}$ & & Decision & Value & & $\begin{array}{c}\text { Decisio } \\
\text { n }\end{array}$ & $\begin{array}{c}\text { Enjoy } \\
\text { ment }\end{array}$ & & $\begin{array}{c}\text { Decisio } \\
\text { n }\end{array}$ & $\begin{array}{c}\text { Motiva } \\
\text { tion }\end{array}$ & & $\begin{array}{c}\text { Decisio } \\
\text { n }\end{array}$ \\
\hline & r-value & p-value & & r-value & p-value & & r-value & p-value & & r-value & p-value & \\
\hline Sex & $-.130 *$ & 0.033 & Reject Ho & -0.072 & 0.241 & $\begin{array}{c}\text { Accept } \\
\text { Ho }\end{array}$ & -0.055 & 0.373 & $\begin{array}{c}\text { Accept } \\
\text { Ho }\end{array}$ & -0.049 & 0.426 & $\begin{array}{c}\text { Accept } \\
\text { Ho }\end{array}$ \\
\hline Birth Order & 0.005 & 0.929 & $\begin{array}{c}\text { Accept } \\
\text { Ho }\end{array}$ & -0.018 & 0.767 & $\begin{array}{c}\text { Accept } \\
\text { Ho }\end{array}$ & -0.069 & 0.262 & $\begin{array}{c}\text { Accept } \\
\text { Ho }\end{array}$ & 0.057 & 0.349 & $\begin{array}{c}\text { Accept } \\
\text { Ho }\end{array}$ \\
\hline $\begin{array}{l}\text { Mother's } \\
\text { Education }\end{array}$ & 0.015 & .808 & $\begin{array}{c}\text { Accept } \\
\text { Ho }\end{array}$ & $.192 * *$ & 0.002 & $\begin{array}{c}\text { Reject } \\
\text { Ho }\end{array}$ & 0.074 & 0.226 & $\begin{array}{c}\text { Accept } \\
\text { Но }\end{array}$ & -0.059 & 0.335 & $\begin{array}{c}\text { Accept } \\
\text { Ho }\end{array}$ \\
\hline
\end{tabular}




\begin{tabular}{|c|c|c|c|c|c|c|c|c|c|c|c|c|}
\hline $\begin{array}{l}\text { Father's } \\
\text { Education }\end{array}$ & 0.104 & 0.09 & $\begin{array}{c}\text { Accept } \\
\text { Ho }\end{array}$ & $.199 * *$ & 0.001 & $\begin{array}{c}\text { Reject } \\
\text { Ho }\end{array}$ & 0.079 & 0.2 & $\begin{array}{c}\text { Accept } \\
\text { Ho }\end{array}$ & -0.074 & 0.227 & $\begin{array}{c}\text { Accept } \\
\text { Ho }\end{array}$ \\
\hline $\begin{array}{l}\text { Mother's } \\
\text { Occupation }\end{array}$ & 0.01 & 0.865 & $\begin{array}{c}\text { Accept } \\
\text { Ho }\end{array}$ & $.151 *$ & 0.014 & $\begin{array}{c}\text { Reject } \\
\text { Ho }\end{array}$ & 0.076 & 0.218 & $\begin{array}{c}\text { Accept } \\
\text { Ho }\end{array}$ & -0.025 & 0.683 & $\begin{array}{c}\text { Accept } \\
\text { Ho }\end{array}$ \\
\hline $\begin{array}{l}\text { Father's } \\
\text { Occupation }\end{array}$ & 0.004 & 0.943 & $\begin{array}{c}\text { Accept } \\
\text { Ho }\end{array}$ & 0.011 & 0.854 & $\begin{array}{c}\text { Accept } \\
\text { Ho }\end{array}$ & -0.056 & 0.366 & $\begin{array}{c}\text { Accept } \\
\text { Ho }\end{array}$ & -0.051 & 0.402 & $\begin{array}{c}\text { Accept } \\
\text { Ho }\end{array}$ \\
\hline $\begin{array}{l}\text { Parent's } \\
\text { Monthly } \\
\text { Income }\end{array}$ & 0.01 & 0.867 & $\begin{array}{c}\text { Accept } \\
\text { Но }\end{array}$ & $.158 * *$ & 0.01 & $\begin{array}{c}\text { Reject } \\
\text { Ho }\end{array}$ & 0.1 & 0.105 & $\begin{array}{c}\text { Accept } \\
\text { Ho }\end{array}$ & 0.012 & 0.852 & $\begin{array}{c}\text { Accept } \\
\text { Но }\end{array}$ \\
\hline $\begin{array}{l}\text { Daily } \\
\text { Allowance }\end{array}$ & 0.042 & 0.491 & $\begin{array}{c}\text { Accept } \\
\text { Ho }\end{array}$ & 0.119 & 0.051 & $\begin{array}{c}\text { Accept } \\
\text { Ho }\end{array}$ & $.142^{*}$ & 0.020 & $\begin{array}{c}\text { Reject } \\
\text { Ho }\end{array}$ & -0.097 & 0.115 & $\begin{array}{c}\text { Accept } \\
\text { Ho }\end{array}$ \\
\hline $\begin{array}{l}\text { Reading } \\
\text { Materials }\end{array}$ & 0.067 & 0.273 & $\begin{array}{c}\text { Accept } \\
\text { Ho }\end{array}$ & 0.073 & 0.233 & $\begin{array}{c}\text { Accept } \\
\text { Ho }\end{array}$ & 0.037 & 0.548 & $\begin{array}{c}\text { Accept } \\
\text { Ho }\end{array}$ & -0.021 & 0.735 & $\begin{array}{c}\text { Accept } \\
\text { Ho }\end{array}$ \\
\hline Gadgets & -0.022 & 0.723 & $\begin{array}{c}\text { Accept } \\
\text { Ho }\end{array}$ & $-.226 * *$ & 0 & $\begin{array}{c}\text { Reject } \\
\text { Ho }\end{array}$ & $-.176^{* *}$ & 0.004 & $\begin{array}{c}\text { Reject } \\
\text { Ho }\end{array}$ & 0.039 & 0.531 & $\begin{array}{c}\text { Accept } \\
\text { Ho }\end{array}$ \\
\hline Time Spent & 0.014 & 0.824 & $\begin{array}{c}\text { Accept } \\
\text { Ho }\end{array}$ & 0.051 & 0.409 & $\begin{array}{c}\text { Accept } \\
\text { Ho }\end{array}$ & 0.031 & 0.62 & $\begin{array}{c}\text { Accept } \\
\text { Ho }\end{array}$ & 0.018 & 0.773 & $\begin{array}{c}\text { Accept } \\
\text { Ho }\end{array}$ \\
\hline Liked & $-.171 * *$ & 0.005 & Reject Ho & $-.121 *$ & 0.048 & $\begin{array}{c}\text { Reject } \\
\text { Ho }\end{array}$ & $-.173^{* *}$ & 0.005 & $\begin{array}{c}\text { Reject } \\
\text { Ho }\end{array}$ & $.190 * *$ & 0.002 & $\begin{array}{c}\text { Reject } \\
\text { Ho }\end{array}$ \\
\hline Disliked &.$-191 * *$ & 0.002 & Reject Ho & 0.028 & 0.646 & $\begin{array}{c}\text { Accept } \\
\text { Ho }\end{array}$ & 0.111 & 0.071 & $\begin{array}{c}\text { Accept } \\
\text { Ho }\end{array}$ & -0.083 & 0.178 & $\begin{array}{c}\text { Accept } \\
\text { Ho }\end{array}$ \\
\hline
\end{tabular}

**Correlation is significant at the 0.01 level (2-tailed)

*Correlation is significant at the 0.05 level (2-tailed)

Respondents' parents' monthly income was significantly related to the value of mathematics $(r=.158$, $\mathrm{p}<.05)$. Thus, the null hypothesis is rejected. The positive correlation implies that the high the monthly income, the better in valuing mathematics. It implies that parents' monthly income was related to valuing mathematics. Family income affects the students in valuing mathematics because most of the respondents' parents were below the minimum income every month. In this case, parents were not fully supported the studies of their children in terms of financial support. Mayer (as cited in Machebe et al., 2017) observed that the children coming from wealthy families have higher chances of succeeding in their life than those children who are coming from low-income families, probably because parents of affluent families spend more on the education of their children because they consider this as their "investments" that would lead to a better future for their children.

It also is noted that respondents' daily allowance was significantly related to enjoyment in mathematics ( $\mathrm{r}=$ $.142, \mathrm{p}<.05)$. Therefore, the null hypothesis is rejected. The positive correlations indicate that the higher the daily allowance, the better enjoyment in mathematics. Meaning, respondents enjoyed learning mathematics when they have ISSN: $2456-7620$ enough allowance to support their mathematics requirements. In support of the result of the study of Yousefi (2010) that daily allowance is a large factor in the learning process and academic achievement of high school learners.

Looking at the profile of the respondents, the data revealed that there is a significant correlation between gadgets used in learning mathematics and the value of mathematics $(\mathrm{r}=-.226, \mathrm{p}<.05)$. Therefore, the null hypothesis is rejected. The negative correlation meant that the less number of cell phone users, the higher the valuing mathematics. This can be analyzed that when respondents less engage in different gadgets, they more valuing mathematics. It indicates that the majority of respondents had a cell phone. It means that they were more engaged in cell phones rather than valuing mathematics. Instead of using it in the mathematics lesson, they were used in other functions such as mobile gaming. Study results supported by the study of Flangan (2011) the children exposed to using gadgets in learning mathematic were less valuing their mathematics lessons.

Respondents' gadgets used in learning mathematics was also found to be significantly related to respondents' enjoyment of the subject $(r=-.176, p<.05)$. Thus, the null 
hypothesis is rejected. The negative correlation indicates that the lower number of cell phones used, the higher the enjoyment in mathematics. This can be analyzed that when respondents less engage in different gadgets, they were more enjoyed in learning mathematics lessons. It indicates that the majority of the respondents had cell phones, it implies that students enjoyed learning mathematics if they lessen the usage of a cell phone because instead of using it in learning, they used it in mobile games, social media, and other entertainment which they found enjoyable rather than studying mathematics lesson.

Respondents' most liked and disliked subject was significantly related to the level of their self-confidence $(r=-$ $.171, \mathrm{p}<.01)$ and $(\mathrm{r}=-.191, \mathrm{p}<0.01)$ respectively. Thus, the null hypothesis is rejected. The negative correlation indicates that the least you like the subject, the high self-confidence in mathematics. On the other hand, the less you disliked the subject, the higher self- confidence in mathematics. Based on the respondents' level of self-confidence had moderately high interpretation, and they agreed to the statement, "I have usually enjoyed studying mathematics in school." It means that the more the respondents enjoy the mathematics classes, the more they will have self-confidence. Van der Bergh (2013) argues that students with high self-confidence believe in their abilities to succeed in learning mathematics, thus overcoming the fear of failing. These students are ready to take mathematical challenges, which in turn increases their academic achievement; otherwise, students with low selfconfidence who do not believe in themselves tend to avoid taking mathematics challenges (Adelson \& McCoach, 2011).

Respondents' most liked subject was significantly related to mathematics subject $(\mathrm{r}=-121, \mathrm{p}<.05)$. Therefore, the null hypothesis is rejected. The negative correlation indicates that the least you liked the subject, the more you valued Mathematics subject. Most of the respondents agreed on the statement "Mathematics is important in everyday life" it means that if the respondents valued the importance of mathematics in everyday life, they don't need to like the subject because having a perception that it was important in everyday life it is enough for them to learn mathematics subject.

The most liked subject was significantly related to mathematics subjects $(r=-.173, p<.01)$. Therefore, the null hypothesis is rejected. The negative correlation indicates that the least you liked the subject, the higher you enjoyed the subject. It means that students who are less liked mathematics subject will surely enjoy learning the subject.
Based on the statements in motivations, most of the respondents were moderately high motivation levels in the statement "studying mathematics makes me feel nervous." it implied that if the students removed their nervous and change into enjoyment, their academic performance will be improved.

According to PISA 2012 results published by OECD (2013), students may learn mathematics because they find it enjoyable and exciting. They further posit that interest and enjoyment affect both the degree and continuity of engagement in learning and the depth of understanding. This means that the more students enjoy doing mathematics, the more they are likely to engage in problem-solving thus enhancing their learning and performance.

Significant relationship was found between most liked subject and motivation $(r=.190, \mathrm{p}<.01)$. Therefore, the null hypothesis rejected. The positive correlation implied that the more you liked the subject the more you motivated in the subject. This means that it was considered as factor of students' motivation in learning mathematics. Most of the statements in motivations were negative statements and moderately high on the statement "Studying Mathematics makes me nervous." it implies that liking the mathematics subjects will motivate them to study and improve their mathematics performance. Moenikia and Zahed-Babelan (2010) pointed out that attitudes of students towards mathematics effects on how well they perform in the subject and how often they engage in the subject.

No significant relationship was found between selfconfidence and profile variables: birth order, mother and fathers' education, mothers and fathers' occupation, parents' monthly income, daily allowance, reading materials, time spent studying mathematics, and gadgets used in learning mathematics. This means that these variables were not influenced with respondents' self-confidence in mathematics.

Likewise, sex, birth order, fathers' occupation, daily allowance, reading materials, time spent studying math, and the most disliked subject was not significantly related to respondents' value of mathematics. Meaning, the respondents' value of mathematics do not influence by the profile variables mentioned.

No significant correlation was also found between profile variables sex, birth order, mother and fathers' education, mothers and fathers' occupation, parents' monthly income, reading materials, time spent studying mathematics, and most disliked subject and respondents' enjoyment of 
mathematics. This proves that these variables do not directly influence respondents' enjoyment of mathematics subject. As of the motivation, aside from the most liked subject, all profile variables sex, birth order, mother and fathers' education, mothers and fathers' occupation, parents' monthly income, daily allowance, reading materials, time spent studying mathematics, and most disliked subject, were not significantly correlated to respondents' motivation to study mathematics. This means that the respondents were motivated to study mathematics because they like the subject.

The findings revealed that sex has a negative correlation in respondents' self-confidence in math, most liked and disliked subject that there is a negative correlation in respondents' self-confidence in mathematics while parents' education, monthly income, gadgets used, and most liked subject were the predictors of the respondents' value of mathematics. Respondents' enjoyment of mathematics was influenced by the daily allowance, gadgets used, and most liked the subject. Interestingly, the most liked subject of the respondents was the only motivator for them to study mathematics.

\subsection{Relationship among profile variables of High School Students and their level of self-efficacy and mathematics performance.}

Presented in Table 13 was the relationship between the profile of the respondents and their self-efficacy and math performance.

Results revealed that respondents' most liked subject is significantly related to the level of self-efficacy towards mathematics $(r=-.225, \mathrm{p}<0.01)$. The analysis found with evidence that the null hypothesis is rejected; Thus, there is a significant relationship between respondents' most liked subject and respondents' level of self-efficacy. The negative correlation indicates that the lesser you liked the subject, the higher self-belief in learning mathematics. Based on the level of self-efficacy of respondents were verbally interpreted as moderately high, and most of them agreed in the statement, "I believe I will be able to use mathematics in my future career when needed." It means that when the respondents were liked more the subject, they tend to believe that selfefficacy will become low.

On the other hand, when the respondents dislike the subject, it means they had high self-efficacy in the subject because they believed they learned well in mathematics lessons, and it is useful in their future career. On these respondents' perceptions in mathematics, they don't need to like mathematics because they know it will help them in their future career and study harder to improve their performance in mathematics. The result was supported by the study findings of Langat (2015) considering students' opinions and beliefs regarding mathematics, how much value and like it and what they forecast for their future education reflect the most vital predictor variables affecting students' achievement. Students with high self-concepts example, those who thought that doing well in mathematics was not difficult and valued the importance of Mathematics were more likely than their peers with low self-concepts to attain a higher mathematics achievement. Moreover, Breen and O'Shea (2010) refer that several studies are showing that self-efficacy is related to engagement in learning, and there is a correlation between self-efficacy and performance on the task

The most disliked subjects were significantly related to respondents' self-efficacy towards mathematics ( $\mathrm{r}$ $=.136, \mathrm{p}<0.05)$. The analysis found with evidence that the null hypothesis is rejected; Thus, there is a significant relationship between respondents' most disliked and selfefficacy in Mathematics. The positive correlation meant that the higher the dislike of the subject, the better level of selfbelief in mathematics. It implies that respondents believed more in their capabilities to perform the mathematics task. The result of the study is in line with the findings of Prakash (2011), which stated that our interest governs our drives, motives, and emotions, but mostly our instinct. In another article entitled" Creating an Interest in Learning Science", Paris and Turner (2010) said that interest plays a vital role in motivating students to study. If the learner has an interest in the subject matter, it more likely that the learner will engage in a good study habit that will help the student expand the knowledge at hand. Realizing the importance of mathematics in their lives would help the respondents to be more motivated to learn its concept. 
Table 13.Relationship among Respondents' Profile, Self-Efficacy, and Math Performance

\begin{tabular}{|c|c|c|c|c|c|c|}
\hline Profile & $\begin{array}{c}\text { Self- } \\
\text { Efficacy } \\
r \text {-value }\end{array}$ & p-value & Decision & $\begin{array}{c}\text { Math } \\
\text { Performance } \\
\text { r-value }\end{array}$ & p-value & Decisiom \\
\hline Sex & -0.076 & 0.218 & Accept Ho & $.153 *$ & 0.012 & Reject Ho \\
\hline Birth Order & 0.008 & 0.897 & Accept Ho & -0.071 & 0.249 & Accept Ho \\
\hline Mother's Education & 0.063 & 0.308 & Accept Ho & $.337 * *$ & 0.000 & Reject Ho \\
\hline Father's Education & 0.088 & 0.153 & Accept Ho & $.306 * *$ & 0.000 & Reject Ho \\
\hline Mother's Occupation & 0.038 & 0.533 & Accept Ho & $.182 * *$ & 0.003 & Reject Ho \\
\hline Father's Occupation & -0.017 & 0.788 & Accept Ho & 0.084 & 0.172 & Accept Ho \\
\hline $\begin{array}{l}\text { Parent's Monthly } \\
\text { Income }\end{array}$ & 0.027 & 0.664 & Accept Ho & $.220 * *$ & 000 & Reject Ho \\
\hline Daily Allowance & 0.053 & 0.39 & Accept Ho & $.158 * *$ & 0.01 & Reject Ho \\
\hline $\begin{array}{l}\text { Mathematics Reading } \\
\text { Materials }\end{array}$ & -0.023 & 0.711 & Accept Ho & 0.006 & 0.925 & Accept Ho \\
\hline $\begin{array}{l}\text { Gadgets used in } \\
\text { Learning Mathematics }\end{array}$ & -0.02 & 0.743 & Accept Ho & $-.160^{* *}$ & 0.009 & Reject Ho \\
\hline $\begin{array}{l}\text { Time Spent Learning } \\
\text { Mathematics }\end{array}$ & 0.05 & 0.413 & Accept Ho & 0.066 & 0.282 & Accept Ho \\
\hline Most Liked Subject & $-.225^{* *}$ & 0 & Reject Ho & -0.118 & 0.054 & Accept Ho \\
\hline Most Disliked Subject & $.136^{*}$ & 0.026 & Reject Ho & 0.02 & 0.749 & Accept Ho \\
\hline
\end{tabular}

$* *$ Correlation is significant at the 0.01 level (2-tailed)

*Correlation is significant at the 0.05 level (2-tailed)

Looking at the respondents' profile and their mathematics performance, it shows that respondents' sex was significantly related to their mathematics performance $(\mathrm{r}=.153, \mathrm{p}<0.05)$. This analysis found with evidence that the null hypothesis is rejected; thus, there is a significant relationship between respondents' sex and their performance in mathematics. This implies that sex greatly influenced the performance of the respondents in mathematics that leads to better achievement and progress. The positive relationship of sex to the respondents had a very satisfactory performance in mathematics than males. EFA (Education for all) Review report (2015) supported by United Nations International Children's Emergency Fund (UNICEF) that reasons why males do not perform well in school because boys are less ready for school, parents tend to view girls as more academically inclined than male. These factors can adversely affect school attendance at performance, as well. Boys from low-income family particularly from the rural areas, are pulled out of school; they are ones most likely to drop-out in order to make a financial contribution to aid the family by taking on jobs that do not require academic skills but rather practical skills, e.g., working as farm helpers or stevedores. (Education for all, 2015).

Respondents' parents' educational attainment was significantly related to their mathematics performance $(r=$ .337 and $.306, p<0.01)$. The analysis found with evidence that the null hypothesis is rejected; thus, there is a significant relationship between parents' educational attainment at their mathematics performance. The positive correlation implied that the parents who have higher educational attainment, the better the child performs in mathematics classes. This implies that parents' educational attainment has an impact on performance in mathematics. Parents can guide their children at home to whatever school tasks are assigned to their children. Given enough knowledge of the parents on the

ISSN : 2456-7620 
tasks of their children will help them guide their children in accomplishing such tasks. It was supported by the findings of Alokan (2013) that educational level played an essential role in influencing the level of academic achievement of their children. On the other hand, in a family where both parents are educated, they are well taken care of for their academic activities. Thus, their educational attainment is relevant to this matter Capuno (May, 2019).

Respondents' mother's occupation were significantly related to their performance in mathematics $(\mathrm{r}=$ $.182, \mathrm{p}<0.01)$. Therefore, the null hypothesis is rejected. This implies that there is a significant relationship between respondents' mother's occupations in the performance in mathematics. Most of the mother's occupations were housewives. It implies that mothers can monitor or guide their children whatever they need in their school, and also mothers can have enough time to take care of their children. According to Parungao (2009), the mother's occupation is significant in the achievement of students and is correlated with academic achievement while the father's occupation does not.

Respondents' parents' monthly income was significantly related to their mathematics performance $(\mathrm{r}=$ $.182, \mathrm{p}<0.01)$. The analysis found with evidence that the null hypothesis is rejected; thus, there is a significant relationship between parents' monthly income at their mathematics performance. The positive correlation meant the higher parents' monthly income, the better performance in mathematics. This implies that parents' monthly income had an impact to their mathematics performance. Their monthly income can reflect the capability of parents to send their children to school. That is why it is essential to assess their monthly income, so it could be the basis for understanding the performance of the respondents in math. The respondents belong to the family below the poverty line struggled to send their children to school because of the financial requirements like the fare of their child going to school, food or snacks, and school supplies that are needed in the child's day to day school tasks. When the child is affected financially, it could have adverse effects on their performance in school because they will feel the stress of having inadequate financial resources. Mayer (as cited in Machebe et al., 2017) observed that the children coming from wealthy families have higher chances of succeeding in their life than those children who are coming from poor families, probably because parents of affluent families spend more on the education of their

ISSN : $2456-7620$ children because they consider this as their "investments" that would lead to a better future for their children.

Respondents' daily allowance was significantly related to their mathematics $(r=.158, p<0.01)$. Thus the null hypothesis is rejected. The positive correlation implies that the higher the daily allowance, the better performance in mathematics. This can be analyzed that when the respondents have enough daily allowance, they tend to have better mathematics performance. Based on the combined respondents' parent monthly income, which indicated below the minimum salary every month, they were not able to give enough daily allowance to their children who can only range in Php10 - Php20 daily. This amount of allowance was not enough for their needs in the school. It was supported by findings of Yousefi (2010) that daily allowance is a large factor in the learning process and academic achievement of high school learners. Adzido (2016) stated that being in low socioeconomic status in terms of reasonable money allowance is no excuse for poor performance.

The table also showed that respondents' gadgets used in learning mathematics significantly correlated with mathematics performance $(r=-.160, p<0.01)$. Thus, the null hypothesis is rejected. The negative correlation indicates that as the number usage of cellphone decreases, the level of performance of respondents in mathematics increases. This can be analyzed that lessens the students' used cellphone, then the level of performance gets higher. Based on the students' gadgets use, majority of them uses a cellphone, that results in a low performance in mathematics because respondents were more engaged in gaming application in cell phone rather than using it in learning, which leads them to unfocused studying mathematics.

It can also be seen that birth order, father's occupation, most liked and disliked subject, mathematics reading materials, and time spent learning mathematics was not significantly related to their mathematics performance.

\section{Relationship between Attitude of High School Students and their self-efficacy in mathematics.}

Table 14 presented the relationship of respondents' attitudes to their self-efficacy.

As reflected in the table, respondents' selfconfidence was significantly related to their self-efficacy. The computed p-value of .325 provides a positive and highly significant relation. Self-confidence towards the studied subject is essential for students to succeed in their field of study. It implies that respondents' self-confidence was led 
them to believe their capabilities to learn more in mathematics lessons, and having high self-confidence can boast the self-beliefs of the respondents. According to Causapin (2012), self-efficacy is beliefs in one capability to organize and execute to courses of action required to produce given attainment. Furthermore, Self-confidence in mathematics refers to student perceptions of self as a mathematics learner that include beliefs about one's own ability to learn and perform well in mathematics (Adelson \& McCoach, 2011)

It was also showed respondents' value of mathematics and self-efficacy is positively related. The computed p-value of .300 proves a positive and highly significant at 0.01 level of significance. The result implies that the more you value certain things, it will lead you to believe in those things. It means that the more you valued mathematics subjects, it will lead you to believe your capabilities to learn more and focus more on your studies in mathematics. Through these perceptions, students were academically performed well. According to the study of Syyeda (2016), if students recognize the importance of mathematics in their lives, they will become motivated to study, practice, and learn the subject.

Furthermore, self-efficacy is the belief in one ability to learn and succeed in school mathematics. A student's conviction that adopting certain behaviors will result in achievement in the mathematics classroom; however, the student defines it. This belief was shown to predict mathematics performance better than any other mathematicsrelated belief construct (Lui, 2009).

Table 14. Relationship of Respondents' Attitudes and Self-Efficacy in Math

\begin{tabular}{lccc}
\hline Attitudes & Self-Efficacy & p-value & Decision \\
\hline Self-Confidence & $.325^{* *}$ & 0.000 & Reject Ho \\
Value & $.300^{* *}$ & 0.000 & Reject Ho \\
Enjoyment & $.468^{* *}$ & 0.000 & Reject Ho \\
Motivation & -0.072 & 0.096 & Accept Ho \\
\hline
\end{tabular}

**Correlation is significant at the 0.01 level (2-tailed)

*Correlation is significant at the 0.05 level (2-tailed)

Respondents' enjoyment in mathematics was expected to have a positive relation to their self-efficacy. The computed p-value of .468 , which is positive, proves a positive and highly significant relationship between respondents' enjoyment and self-efficacy in mathematics. It indicates that the more you enjoyed the mathematics subject, it leads the respondents to believe more about their capabilities to do their mathematics-related activities. Most of the respondents had a high level of enjoyment in mathematics and had a moderately high level of selfefficacy. Most of them agreed that mathematics would help them to solve problems in different areas. They also believe that mathematics will be needed in their future career, respectively. The statements lead to the respondents to enjoy and believe in their selves to improved their mathematics skills. It was also means that both enjoyment and selfefficacy were affecting their affective aspect of the respondents. The result of the study supported by the study of Prakash (2011) stated that our drives, motives and emotions govern our interests, but mostly our instincts. On the other hand, enjoyments were drives the respondents' interest, emotions, and motives were driven respondents' self-efficacy towards mathematics.

Respondents' motivation is assumed to have a positive relationship to self-efficacy but the computed pvalue of -.0 .072 , which is negative and provides no significant relationship. The null hypothesis was accepted because a positive and significant relationship between attitudes and self-efficacy of the respondents was not found. It can be noticed from the statements in motivation that the respondents had moderately high motivation in mathematics, and most of them had moderately high motivation in the statements studying mathematics were makes them feel nervous. It means that motivation statements were negative. It implies that despite respondents feel nervous in mathematics lessons, it does not affect their mathematics self-efficacy, and they still believed to themselves in doing their mathematics task. This agrees to Kundus and Ghose (2016), in their study, shows that the attitudes towards the subject strongly influence self-efficacy in mathematics. It 
was further supported by Altura and Yacizi (2010) that students with a positive attitude to mathematics as a friendly tool or a challenge. This boosts their confidence and thus increases their self-efficacy. However, the Students are intrinsically and extrinsically motivated to learn mathematics if they desire to do so after finding the learning of mathematics engaging (OECD, 2013).

Results revealed significant correlations among selfconfidence, value, enjoyment, and self-efficacy.

\section{Relationship between Attitude of High School Students and their performance in mathematics}

It can be observed that the respondents' value towards mathematics was significantly related to their mathematics performance $(r=0.188, p<0.01)$. Thus, the null hypothesis is rejected. The results of the statistical analysis indicated that value accounted for a significant relationship to the math performance of the respondents. Therefore, respondents' value of learning mathematics is the predictor of their performance. This implies that students' value of Mathematics was influenced by their attitudes and mathematics performance towards the subject. If students recognize the value of mathematics in their future endeavors, they will become more motivated to study the subject. The positive relationship of the value of mathematics and students' performance in mathematics meant that the higher their perception of the value of mathematics, the higher the level of their performance. Students value the usefulness of mathematics in their everyday life because they believe that they can use it in the future. According to Adelson and McCoach (2011), perceived usefulness refers to students' perception of the importance of mathematics in the present everyday life and the future. Syyeda (2016) opined that the perceived usefulness of mathematics is believed to influence students' attitudes towards the subject. If students recognize the importance of mathematics in their lives, they will become motivated to study, practice, and learn the subject simultaneously.

It is also observed that respondents' motivation towards Mathematics was significantly and negatively related to their mathematics performance. The negative value $r=-0.326$ shows that the lower level of motivations, the higher the respondents' performance in mathematics. Based on the statements were the respondents answered in their level of motivation towards mathematics, they had moderately high level of motivation towards mathematics and most of them were a moderately high-level interpretation in the statement "studying mathematics makes me feel nervous". It means that if the respondents lessen their nervousness in studying mathematics lesson, they had good academic performance in mathematics because having a positive motivation in mathematics it leads to better performance. The findings further support by the study of Ismail (2009), when mathematics is found enjoyable, it affects the student's motivation to learn. Furthermore, students' engagement in motivational regulation is a function of their existing motivation beliefs, and attitudes ( Wolters \& Benzon, 2013).

Table 15. Relationship of respondents' Attitudes and Math Performance

\begin{tabular}{lccc}
\hline Attitudes & Math First Quarter Grade & p-value & Decision \\
\hline Self-Confidence & -0.04 & 0.52 & Accept Ho \\
Value & $.188^{* *}$ & 0.002 & Reject Ho \\
Enjoyment & 0.115 & 0.06 & Accept Ho \\
Motivation & $-.326^{* *}$ & 0.000 & Reject Ho \\
\hline
\end{tabular}

It can also be noted that enjoyment was positively but not related to their mathematics performance. The positive value of $\mathrm{r}=0.115$ shows that enjoyment was not significantly related to their mathematics performance. It implied that when the students know the value of mathematics in their lives, respondents were obliged to learn their mathematics lesson even though they were not felt enjoyable with the subjects. Based on the study result Syyeda (2016) of the perceived usefulness of mathematics is

ISSN: 2456-7620 believed to influence students' attitudes towards the subject. If students recognize the importance of mathematics in their lives, they will become motivated to study, practice, and learn.

It can also be seen that the self-confidence was not related to mathematics performance. Findings were contrary to the findings of the study by Hannula, Maijala, and Pehkonen $(2004,2009)$, who stated that self-confidence is an essential factor that influences students' learning, which in 
turn affects their performance in Mathematics. Furthermore, Van der Bergh (2013) argues that students with high selfconfidence believe in their abilities to succeed in learning mathematics, thus overcoming the fear of failing.

\section{Relationship between Self-Efficacy and Math Performance}

Table 16 presents the regression analysis results of respondents' self-efficacy and mathematical performance.

It can be observed that respondents' self-efficacy was positively but not significantly related to their mathematics performance. The positive value of 0.021 shows that self-efficacy does not significantly influence the respondents' mathematical performance. This result suggests that respondents' self-efficacy does not predict their mathematics performance. This can be attributed to the school environment. Farmers mainly inhabit rural communities. Therefore, these communities do not attract some amenities like pipe-borne water, electricity, right roads, and well-equipped schools. The government's reluctance to put amenities in these areas may be due to insensitivity to the plight of the population that is found in the barangays. Many of the barangays generally lack good educational facilities, thus, affecting their self-efficacy and mathematics performance. Students in rural and urban areas tend to perform differently in mathematics. This was supported by Onoyase (2015) in her study, which showed that there was a significant difference in the academic performance among students in urban, semi-urban, and rural secondary schools in English Language, mathematics, biology, chemistry, and geography. Owoeye and Yara (2011) have proven that students in urban areas had better academic achievement than their rural counterparts. On the contrary, the findings of Bondoc (2015) show a significant relationship between students' self-efficacy and their performance in mathematics. Furthermore, psychologists and educators have never insisted that self-efficacy was neither the most important nor the most significant predictor of academic performance (Schunk, 2009).

Table 16.Relationship between Respondents' Self-Efficacy and Math Performance

\begin{tabular}{cccc}
\hline \multirow{2}{*}{ Self-Efficacy } & Math First Quarter Grade & p-value & Decision \\
\cline { 2 - 4 } & 0.021 & 0.727 & Accept Ho \\
\hline
\end{tabular}

\section{CONCLUSION AND RECOMMENDATIONS}

This study assessed the attitudes and self-efficacy of students towards mathematics performance. The respondents' first-quarter grade was described as approaching proficiency, which means students performed not very well in their mathematics performance. The respondents' attitudes towards mathematics were moderately high in terms of their self-confidence, high attitude on their value of mathematics, high attitudes in enjoyment in learning mathematics, and moderately high attitude on motivation to learn mathematics. The respondents' sex, most liked, and disliked subject predicts respondents' self-confidence in mathematics while parents' education, monthly income, gadgets used, and most liked subject were the factors of the respondents' value of mathematics. The daily allowance influenced respondents' enjoyment of mathematics, gadgets used, and most liked the subject. Most liked the subject of the respondents was the only motivator for them to study mathematics. Among the profile variables studied, most liked and most disliked subjects influenced respondents' selfefficacy. Some of the respondents' profile that influences math performance was sex, parents' education, mothers' occupation, and gadgets used in learning mathematics. Educated parents influenced their child's math performance.

Respondents' self-efficacy influenced attitudes components self-confidence, value, and enjoyment of the respondents. Attitudes components value and motivation of the respondents towards mathematics were associated with their performance. The self-efficacy of the respondents does not factor in their mathematics performance. It is recommended that students may study harder to improve their performance in mathematics. They should develop a positive attitude towards the subject by active participation in group tutorial sessions. Students may exert more effort to improve their attitudes towards mathematics by enhancing their self-confidence to become more motivated to learn mathematics. Similar research may be conducted in other districts of Aurora to justify the findings of this study. Other observable variables that might have an association with students' attitudes, self-efficacy, and performance may be included, like conceptual understanding of mathematics, study habits, and teaching methods. 
Further research study may be conducted to determine the factors contributing to the attitudes and selfefficacy in mathematics. Teachers may maintain a positive school climate to ensure a safe learning environment for the student. Teachers may help the learners develop their high self-belief to perform in mathematics by employing creative teaching and learning strategies that will make the learners more interested to learn math concepts and theories. Parents may guide and help their children in difficulties of studying Mathematics, which will likewise move them to understand the causes of their children's negative attitudes towards Mathematics. School administration may propose plans to improve the Mathematics program of their school adapted to the needs, interests, and problems of the students, which may be necessary for promoting a better academic performance by increasing and strengthening higher levels of achievement and motivation of the students.

\section{REFERENCES}

[1] Adamos, E. M., 2010. Students' profiles and scientific abilities as predictors of performance in Chemistry. Unpublished Master's Thesis. Aurora State College of Technology, Baler, Aurora.

[2] Akin, Ahmet,(2011), "The Relationship Between Mathematics Anxiety, Math Attitudes, and Self-efficacy. A Structural Equation Model" STUDIA PSYCHOLOGICA, 53, 2011, 3

[3] Alina, Hannula, (2009); Pepe \& Smith (2002). Attitude towards Mathematics: Emotions, Expectations, and Values. Educational Studies in Mathematics, 49-25-46.

[4] Allan Wigfield, Jacquelynne S. Eccles, and Judith L. Meece, (2009) "Predictors of Math Anxiety and Its Influence on Young Adolescents' Course Enrollment Intentions and Performance in Mathematics. Journal of Educational Psychology.

[5] ANIGBO, Leonard Chinaedum, (2016), "Factors Affecting Students' Interest in Mathematics in Secondary Schools in Enugu State", International Journal of Education and Evaluation ISSN 2489-0073 Vol. 2 No.1 2016

[6] Bandalos, D. L., Yates, K., \& Thorndike-Christ, T. (2009). Effects of math self-concept, perceived self-efficacy, and attributions for failure and success on test anxiety. Journal of Educational Psychology, 87(4), 611-623. DOI: 10.1037/00220663.87.4.611

[7] Bandura, A. (2009). Social learning theory. New York: General Learning Press.

[8] Bondoc, John Mark F. (2015)." Level of Anxiety and selfefficacy in Mathematics and its Relationship to their Mathematics Performance."

[9] Capuno, Reylano, et al. (2019), "Attitudes, Study Habits, and Academic Performance of Junior High School Students in
Mathematics" INTERNATIONAL ELECTRONIC JOURNAL OF MATHEMATICS EDUCATION e-ISSN: 1306-3030. 2019, Vol. 14, No. 3, 547-561 https://doi.org/10.29333/iejme/5768

[10] DepEd Discussion Paper. (2010) Discussion Paper on the Enhanced K-12 Basic Education Program. Retrieved from: ceap.org.ph/upload/...17115829500_1.pdf

[11] DepEd Order No. 31, s.2012, Policy Guidelines on the Implementation of Grade 1-10 of the K-12 Basic Education Curriculum (BED) Effective School Year 2012-2013. Retrieved from http://www.deped.gov.ph

[12] Di Martino, P., \& Zan, R. (2010). "Me and maths": Towards a defination of attitude grounded on students' narratives. Journal of Mathematics Teacher Education, 13, 27-48.

[13] Education for All (EFA) National Review Report (2015). Pp42-45 Retrieved http://www.google.com/?gfe_rd=cr\&ei=CDH2Vo7VIcnC8gfg kK2ICA7gws_rd=ssl\#q=national+efa+2015+review

[14] Erdem, Emine, (2015) "The Relationship Between Selfefficacy and Attitudes of Chemistry Teacher Candidates" education in the 21st centuryVolume 63, 2015

[15] Fennema, E., \& Sherman, J. A. (2009). Fennema-Sherman Mathematics Attitudes Scales: Instruments designed to measure attitudes toward the learning of mathematics by females and males. Journal for Research in Mathematics Education, 7, 324-326. DOI:10.2307/748467

[16] Franz, Janie. (2016) Gale Encyclopedia of Children's Health: Infancy through Adolescence. Copyright 2006 Thomson Gale. Retrieved from http:// www. encyclopedia. com/ topic/Birth_order.aspx

[17] Gacayan, J. C. C2013). Predictors of Student's Achievements in Chemistry in Dilasag, Aurora. Unpublished master's Thesis. Aurora State College of Technology, Zabali, Baler, Aurora

[18] Han, Sandie, Liou, e.al.(2015), "Self-efficacy and Attitudes Towards Mathematics of Undergraduates:a U.S. and Taiwan C Journal of Mathematics Education (C) Education for All Spring 2015, Vol. 8, No. 1, pp. 1-15 omparison"

[19] Hyde, J. S., Fennema, E., \& Lamon, S. J. (2009). Gender differences in mathematics performance. Psych Bull, 107, 139155

[20] Jaen, M. C. A. and Bacsay, E. S. (2016). Curiosity, Motivation, Attitude, Gender, and Mathematics Performance. The Normal Lights, Vol. 10, No. 2

[21] Kannan, B. S., Sivapragasam, C., and Senthilkumar, R. (2015). Attitude of Secondary School Students Towards Mathematics. International Journal of Multidisciplinary Research and Modern Education, Vol. 1, Issue 11

[22] Keller, C. (2009). Effect of teachers' stereotyping on students' stereotyping of mathematics as a male domain. Journal of Social Psychology, 141, 165-173. DOI:10.1080/00224540109600544.

[23] Klassen, R. M. (2009). Too Much Confidence? The SelfEfficacy of Adolescents with Learning Disabilities. In F.

ISSN : 2456-7620 
Pajares \& T. C. Urdan (Eds.), Self-efficacy beliefs of adolescents (pp. xii, 367 p.). Greenwich, Conn.: IAP Information Age Pub., Inc.

[24] Kosha, R., Kosha, M., and Gupta, A. (2013). Students' Mathematics Academic Performance: An Interaction of Inputs from the Students, Schools, and Voters. Retrieved from https://brill.com/.

[25] Koyuncu1, Bengisu,*,(2018), "Predictive Value of Sense of Self-efficacy and Attitudes of High School Students for Their Resistance to Mathematics" Universal Journal of Educational Research 6(8): 1629-1636, 2018 http://www.hrpub.org DOI: 10.13189/ujer.2018.060801

[26] Kundu, A., and Ghose, A. (2016). The Relationship Between Attitude and Self Efficacy in Mathematics Among Higher Secondary Students. IOSR Journal of Humanities and Social Science (IOSR-JHSS) Volume 21, Issue 4, Ver. 05 PP 25-31

[27] Kunhertanti, K., and Santosa, R. H. (2018). The Influence of Students' Self Confidence on Mathematics Learning Achievement J. Phys.: Conf. Ser. 1097012126

[28] Langat, Alphine C.(2011) ,"Students' Attitudes and their Effects on Learning and Achievement in Mathematics: a case study of Public Secondary Schools in Kiambu County, Kenya." https://goo.gl/MuQxNh E55/24385/2011

[29] Levine, M. (2012). A mind at a time: How every child can succeed. Simon and Schuster. Retrieved from https://goo.gl/RxNkxu

[30] Liu, O. L. (2009). An Investigation of Factors Affecting Gender Differences in Standardized TestMaio, G. and Haddock G. (2010). The Psychology of attitude and attitude change. London: SAGE Publications Ltd.

[31] Mata, M. L., Monteiro, V. and Peixoto, F. (2012). Attitudes towards Mathematics: Effects of Individual, Motivational, and Social Support Factors. Hindawi Publishing Corporation, Child Development Research. DOI:10.1155/2012/876028

[32] Ma, X. \& Xu, J. (2009). The causal ordering of mathematics anxiety and mathematics achievement: A longitudinal panel analysis. Journal of Adolescence, 27, 165-179.

[33] Martin, C. L., \& Ruble, D. (2009). Children's search for gender cues: Cognitive perspectives on gender development. Current Directions in Psychological Science, 13, 67 -70. doi: $10.1111 /$ j . 09637214.2004 .00276.x.

[34] Martino, Pietro D. et al., (2009), 'Me and maths': towards a definition of attitude grounded on students' narratives" J Math Teacher Educ (2010) 13:27-48 DOI 10.1007/s10857-0099134-z

[35] Mathematical Problem-Solving. Contemporary Educational Psychology, 20(4), 426-443. DOI: 10.1006/ceps.1995.1029

[36] Mohamed, B. A., Waheed, R. B. (2011). Predicting high school students' cognitive engagement and achievement: Contributions of classroom perceptions and motivation. Contemporary educational psychology, 29(4), 462-482. Retrieved from https://goo.gl/CRZYo3
[37] Mensah, J. K., Okyere M., and Kuranchie, A. (2013). Student attitude towards Mathematics and performance: Does the teacher attitude matter? Journal of Education and Practice, Vol. 4, No. 3

[38] Mutodi, Paul and Ngirande, Hlanganipai (2014), "The Influence of Students Perceptions on Mathematics Performance.A Case of a Selected High School in South Africa" E-ISSN 2039-2117, ISSN 2039-9340 Mediterranean Journal of Social Sciences MCSER Publishing, Rome-ItalyVol 5 No 3

[39] Nicolaidou, M. and Philippou, G. (n.d.). Attitudes Towards Mathematics, Self-Efficacy and Achievement in ProblemSolving. European Research in Mathematics Education III.

[40] Owoeye, J. S., and Yara, P. O. (2011). School Location and Academic Achievement of Secondary School in Ekiti State, Nigeria. Asian Social Science, Vol. 7, No. 5.

[41] Pintrich, P. R. (2009). A conceptual framework for assessing motivation and self-regulated learning in college students. Educational Psychology Review, 16, 385-407.

[42] Partrige, Julie et al. (2013), "Theoretical perspectives: Eccles' expectancy-value theory" http://www.open.edu/openlearn/body-mind/physical-activityfamily-affair/content-section-0

[43] Pilayan, et al., (2013) "Problems Met by the $4^{\text {th }}$ year student in Learning Trigonometry in Wesleyan University-Philippines"

[44] Pagtulan, EDUARD A; and Tan, DENIS A.,(2018) "students' mathematics performance and self-efficacy beliefs in a rich assessment tasks environment"ISSN 2019-280

[45] Rammstedt, B., \& Rammsayer, T. H. (2009). Sex differences in self-estimates of different aspects of intelligence. Personality and Individual Differences, 29, 869-880.

[46] Recber, Senol, et al. (2018), "Investigating self-efficacy, anxiety, attitudes and mathematics achievement regarding gender and school type," anales de psicología, 2018, vol. 34, ${ }^{\circ}$ $1 \quad$ (January), 41-51 http://dx.doi.org/10.6018/analesps.34.1.229571 @ Copyright 2018: Editum. Servicio de Publicaciones de la Universidad de Murcia. Murcia (Spain) ISSN print edition: 0212-9728. ISSN web edition (http://revistas.um.es/analesps): 1695-2294

[47] Repuya, Christian R. et al." (2018) Self-efficacy and Attitude towards Mathematics: Its Implication to Mathematics Learning Asia Pacific Journal of Social and Behavioral Sciences Volume 152018 ORCID No. 0000-0002-0121-6431.

[48] Rogel, Richelle I. (2012). "Academic Behavior and Performance of Third Year Students of General Emilio Aguinaldo National High School, Division of Cavite." Published Master Thesis.pp.47. Retrieved from http://www. academia.edu

[49] Sangkap, P. G. A. (2010). Mathematics-related Beliefs of Filipino College Students: Factors Affecting Mathematics and Problem-Solving Performance. Procedia Social and Behavioral Sciences, 8, 465-475 
[50] Salaria, Neeru (2012). Meaning of the Term-Descriptive Survey Research Method. Retrieved from http://www.ijtbm

[51] Sarma, R. S., \& Puri, M. (2014). Early predictors of high school mathematics achievement. Psychological science, 23(7), 691-697. Retrieved from https://goo.gl/g8Be7S

[52] Schunk, D. H. M., J.L. (2009). Self-Efficacy Development in Adolescence. In F. Pajares \& T. C. Urdan (Eds.), Self-efficacy beliefs of adolescents (pp. xii, 367 p.). Greenwich, Conn.: IAP - Information Age Pub., Inc.

[53] Sherman, B.F., and D.P. Wither (2009). Mathematics anxiety and mathematics achievement. Math. Educ. Res. J., 12: 138150.

[54] Shih, S. (2005). Role of achievement goals in children's learning in Taiwan. Journal of Educational Research, 98(5), 310-319.

[55] Syyeda, M. (2016). Interest, enjoyment, and pride after failure experiences? Predictors of students' state-emotions after success and failure during learning in mathematics. Educational Psychology, 31(7), 779-807. Retrieved from https://goo.gl/pcxkYn

[56] Tsabalala, A. M. I. G., \& Ncube, D. P. (2016). A confirmatory factor analysis of attitudes toward mathematics inventory (ATMI). The Mathematics Educator, 15(1), 121-135. Retrieved from https://goo.gl/brPi4V

[57] Ukueze, A., and Van der Bergh, M. (2009). Learner variable on academic performance: Adjustment of Junior Secondary Student. The Counselor, 23 (2): 172-183

[58] Unlua,Melihan,(2010)" The relationship between geometry attitudes and self-efficacy beliefs towards geometry" Procedia Social and Behavioral Sciences 9 (2010) 1325-1329

[59] Waini, I. et. al (2014). Self-Confidence in Mathematics: A case Study on Engineering Technology Students in FTK, UTeM. International Journal for Innovation Education Research, Vol. 2-11

[60] Wigfield, A., \& Eccles, J. S. (2009). Expectancy-value theory of motivation. Contemporary Educational Psychology, 25, 6881.

[61] Wu, Y. (2017). Students' Attitude towards Mathematics and Their Math-Gender Stereotype: Gender and Year Levels, Paper presented at the HDR summer school, Faculty of Arts and Education, Deakin University (Geelong Waterfront) $24^{\text {th }}$ $26^{\text {th }}$ February.

[62] Yasar, M. (2016). High School Students' Attitudes Towards Mathematics. Eurasia Journal of Mathematics, Science \& Technology Education, 12(4), 931-945

[63] Yavuz Mumcu, H., \& Cansiz Aktas, M. (2015). Multi-program high school students.' attitudes and self-efficacy perceptions toward mathematics. Eurasian Journal of Educational Research, 59, 207-226 http://dx.doi.org/10.14689/ejer.2015.59.12

[64] Yousefi, Fayegh. et al. (2010) “ The Effects of Family Income on Test Anxiety and Academic Achievement among Iranian High School Students." Department of Psychiatry, Faculty of
Medicine, Kurdistan University of Medical Science. SanandajIran. Retrieved from http://citeseerx.ist.psu.edu 